\title{
Kinetics and evaporation of water drops in air
}

H.J. Holterman

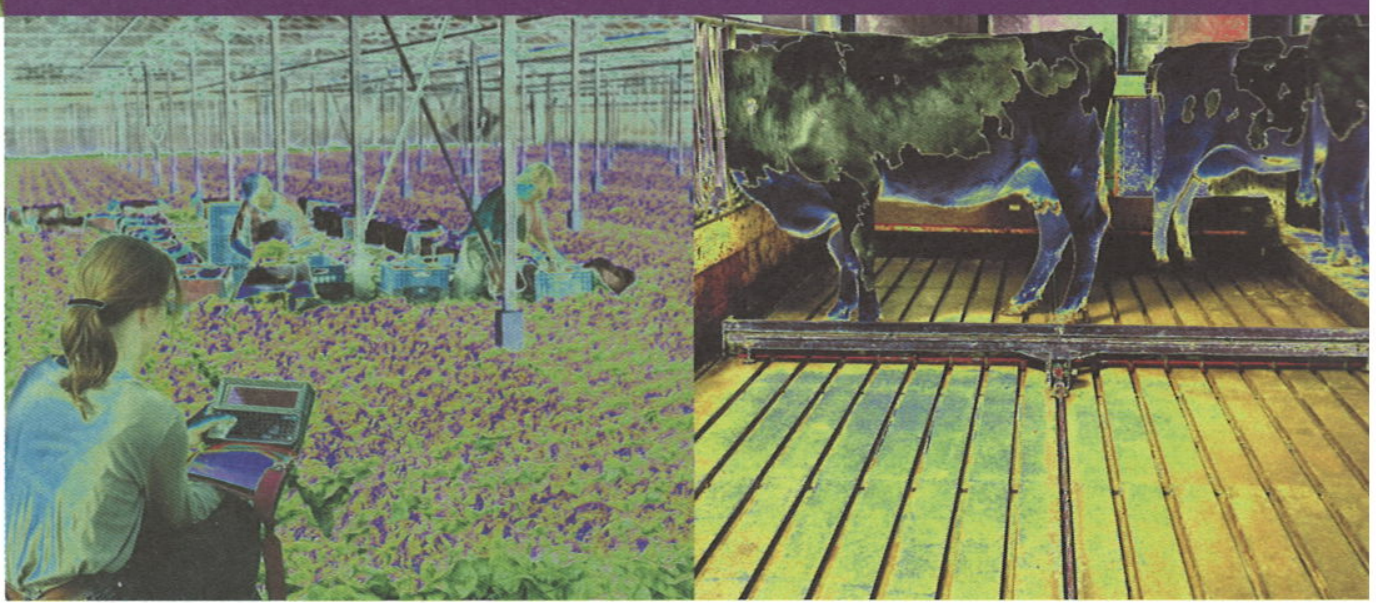

I MAG 


\section{Kinetics and evaporation of water drops in air}

H.J. Holterman

IMAG report $2003-12$

Wageningen UR

July 2003 
CIP-DATA ROYAL LIBRARY, DEN HAAG, NL

Kinetics and evaporation of water drops in air/H.J. Holterman - Wageningen: IMAG

(Report 2003-12/Wageningen UR, Instituut voor Milieu- en Agritechniek; 2003)

ISBN 90-5406-234-7

NUGI 849/NUR 950

DOI: $\underline{\text { https://doi.org/10.18174/562300 }}$

Trefw.: drift,.druppels, water, modellen, kinetisch model, verdamping

(C) 2003 IMAG, Postbus 43 - 6700 AA Wageningen

Telefoon 0317-476300

Telefax $\quad 0317-425670$

Alle rechten voorbehouden. Niets uit deze uitgave mag worden verveelvoudigd, opgeslagen in een geautomatiseerd gegevensbestand, openbaar gemaakt, in enigerlei vorm of op enigerlei wijze, hetzij elektronisch, mechanisch, dor fotokopieën, opnamen of enig andere manier zonder voorafgaande schriftelijke toestemming van het instituut.

All rights reserved. No part of this publication may be reproduced, stored in a retrieval system of any nature, or transmitted, in any form or by any means, electronic, mechanical, photocopying, recording or otherwise, without the prior permission of the institute. 


\section{Abstract}

Holterman, H.J. Kinetics and evaporation of water drops in air.

IMAG, Wageningen, The Netherlands. May 2003. 67 pp.

English, with Dutch summary.

In chemical crop protection, the amount of deposition and drift is the cumulative result of a large number of individual drops travelling through air. When investigating the flow of drops through air, one has to be aware of kinetic aspects as well as evaporation of water from the drops.

A theoretical discussion of kinetic aspects is carried out for sedimentation of drops in still air. The presented theory can be used for windy situations as well, with basically straightforward adaptations. The theoretical discussion of evaporation deals with aqueous drops in air. This derivation bears considerably on the kinetic aspects of drops in air. A major application for both kinetic aspects and evaporation is their implementation in the IDEFICS spray drift model. However, the kinetic and evaporation models are presented in a general way, and can be implemented in other applications as well. Extension to systems based on solvents other than water can be performed easily.

Keywords: spray drift, theory, kinetic model, evaporation model, water drops 


\section{Preface}

For a clear and systematic understanding of the processes involved with spray application and spray drift one has to consider kinetic aspects of the droplets and evaporation of spray water. Often a discussion of this kind of basic phenomena is likely to drown in the extensive discussion of the 'higher goal' of practical applications (such as a full-scale model of a particular 'high-end' phenomenon).

Nevertheless, we felt there was need for a comprehensive discussion on some theoretical aspects involved with airborne sprays. Often practice and theory follow different paths in time. Also in this case: the current report presents theoretical aspects that already have been used in specific applications like our IDEFICS spray drift model. Still, this report is a welcome addition to the range of reports where applications of the IDEFICS model are used. And what is more, the general approach of the presented theory reaches for a much broader use than this particular application alone: implementation in other (future) spray models, for other crop types and using other types of spray liquid may all profit from the basic requirements discussed in this report.

This investigation is part of research programme 359 (Emission, emission reduction methods and environmental risk of crop protection agents), granted by the Dutch Ministry of Agriculture, Nature Management and Fisheries (LNV).

Ir. Jan Huijsmans

Head of Crop Production Engineering Department 


\section{Contents}

1 Introduction $\quad 9$

2 Sedimentation of spherical drops in air 11

2.1 Introduction 11

2.2 Laminar flow 12

$\begin{array}{ll}2.3 \text { General flow } & 13\end{array}$

2.4 Empirical model of drag coefficient 14

$\begin{array}{lll}2.5 & \text { Sedimentation velocity } & 16\end{array}$

$\begin{array}{ll}2.6 & \text { Relaxation time } \\ & 17\end{array}$

$\begin{array}{lll}2.7 & \text { Stopping distance } & 19\end{array}$

2.8 Impaction on spherical targets 24

2.9 Trajectory of a single drop in a cross wind 26

2.10 Discussion 28

3 In-flight evaporation of drops 31

3.1 Introduction 31

3.2 Decrease of drop diameter with time $\quad 33$

3.2.1 General derivation 33

3.2.2 Evaporation rate at sedimentation velocity 35

$\begin{array}{lll}3.3 & \text { Lifetime of an evaporating water drop } & 38\end{array}$

$\begin{array}{ll}3.4 & \text { Initial cooling-down period } \\ 3.5 & 40\end{array}$

$\begin{array}{lll}3.5 & \text { Validation } & 44\end{array}$

3.6 Discussion 46

References $\quad 49$

Summary 51

Samenvatting $\quad 53$

Appendix A. Molecular view of evaporation 55

Appendix B. Evaporation as a process of diffusion $\quad 59$

$\begin{array}{ll}\text { Appendix C. Vapour pressure and humidity } & 63\end{array}$

$\begin{array}{ll}\text { Appendix D. Various empirical equations } & 65\end{array}$ 


\section{Introduction}

Theoretical studies of spray drift can be rudely divided into cloud-based and droplet-based studies. Typically cloud-based studies are more appropriate for describing long-distance drift, while droplet-based studies have advantages for near-downwind drift and deposition, particularly when non-smooth surfaces and objects are present (like crop edges and ditches). The IDEFICS model is a droplet-based spray drift model developed at IMAG in the 90's (e.g. Holterman et al., 1997). Generally, when studying droplet transport through air, some knowledge of kinetics is necessary. When these droplets mostly consist of water, in-flight evaporation should be accounted for as well. This report deals with the theory of both kinetic and evaporative aspects of in-flight water drops.

The report is divided into two main chapters: one on kinetics and another on evaporation. At first dealing with these two subject in one report may seem strange. Indeed, the chapter on kinetics can be read independently. However, understanding evaporation of drops in air requires references to kinetic aspects.

In chapter 2 the flow of a spherical drop through air is described. The drop experiences forces like gravity and air resistance, which determine its path through air. Initial velocity, drop size and wind velocity are important factors. After a discussion of laminar and turbulent flow, slightly more practical aspects like sedimentation velocity, relaxation time and stopping distance are discussed. The final sections on impaction and trajectory calculation have clearly practical applications for studying drift and deposition both theoretically and experimentally. The theory presented in this chapter is implemented firmly in the IDEFICS spray drift model.

Chapter 3 deals with evaporation of aqueous drops in air. Important parameters are ambient air temperature and relative humidity, as well as aspects related to the drop itself: its size and relative velocity. In a first approximation the transient processes that occur shortly after droplet creation are neglected, resulting in a relatively simple description of evaporation rate and droplet lifetime. However, for a full understanding of evaporation the transient processes should be dealt with too. These processes comprise velocity adaptation (usually rapid deceleration) and cooling-down (due to evaporation) of the droplet.

Fortunately, it turns out that the time scales involved with the transient processes are very short and in all practical cases these processes can indeed be neglected. At the end of the chapter a section on validation offers experimental support for the theory presented. 
Both the theory on kinetics and that on evaporation are implemented in the IDEFICS spray drift model. However, the theory is not limited to this single model. In fact, in almost all cases where droplet transport through air is considered, the presented theory is applicable. 


\section{Sedimentation of spherical drops in air}

\subsection{Introduction}

For many decades the resistance of a rigid object to a fluid flowing around it was evaluated by determining the so-called Reynolds' number. For relatively low Reynolds' numbers (i.e. relatively low-speed flow) the fluid flow around the object is laminar: it consists of imaginary fluid layers with different velocities, flowing smoothly around the object. Accidental disturbances in the flow field will decrease and vanish in laminar flow. The resistance or 'drag force' onto the object is determined by the friction between these fluid layers. For a spherical object, the drag force is described by Stokes' law (see Section 2.2); it depends on liquid viscosity, object size and relative velocity of the liquid with respect to the object.

At increasing Reynolds' numbers small disturbances in the laminar flow field will no longer vanish. Instead, they may increase and eventually the laminar structure of the flow will be lost completely, apart from a laminar boundary layer near the surface of the object. The main flow is said to be a turbulent flow. Now the drag force is determined mainly by friction in the turbulent parts of the liquid; the contribution of friction in the laminar 'shell' around the object is relatively small. At the rear end of the object the boundary layer will eventually come off, creating a turbulent wake. In turbulent flow Stokes' law no longer is applicable, therefore also the term 'non-Stokes' flow is used. In turbulent flow, the drag force can be described by introducing a 'drag coefficient', which depends on the shape of the object (and often on Reynolds' number too). Physically the transition from laminar to turbulent always occurs gradually, but for convenience of discussion laminar and turbulent flows are considered as two clearly distinct flow regimes. Mathematically laminar flow turns out to be a 'special case' of the general flow equations used to describe turbulent flow (Section 2.3).

Liquid drops falling through or floating in air often can be described in the same way, provided that the drops can be regarded spherical throughout. In most practical cases, including spray application in crop protection, the flow of air around the drops is turbulent because Reynolds' numbers are too high. To describe the path of a falling drop in air, one needs to know the drag coefficient as a function of Reynolds' number. In literature the relation between drag coefficient and Reynolds' number always is empirical, and usually is described in such a way that mathematical handling (primarily analytical integration) is facilitated. In many cases a set of relations comes forth, each of which is valid only for a relatively small range of Reynolds' numbers (see e.g. Eck, 1961). To cover a wide range of Reynolds' numbers, the whole set must be used, often with discontinuities when going from one relation to another. 
In the spray drift model IDEFICS (Holterman et al., 1997) the paths of many drops, starting at the outlet of a spray nozzle, are accurately described to calculate downwind spray deposits and drift. In spray applications Reynolds' numbers roughly range from 0 to 2000 (see Section 2.4); to compute the drag coefficient for this range at least three relations as mentioned by Eck (1961) would be required. These considerations asked for a new and wide-range relationship between drag coefficient and Reynolds' number. In our computerised era mathematical integrability of equations no longer is a required asset, so attention could be focused completely on aptness of the relationship itself.

This chapter describes the drag forces on a spherical drop in air, and a relatively simple, wide-range, empirical relationship between drag coefficient and Reynolds' number. Subsequent quantities like sedimentation velocity, relaxation time and 'stopping distance' are discussed also.

\subsection{Laminar flow}

Air resistance of arbitrarily shaped objects in an air stream is usually described using Reynolds' number Re:

$$
R e=\frac{\rho_{a} D v}{\eta_{a}} \quad[\text { dimensionless }]
$$

where $D$ is a characteristic measure of the size of the object, $v$ is its velocity relative to the air stream, $\rho_{a}$ is the density of air, and $\eta_{a}$ is the dynamic viscosity of air. For spherical objects the obvious size parameter $D$ is the diameter of the sphere.

For $\operatorname{Re}<0.25$ (see Section 2.4) flow around the sphere is completely laminar. The drag force is equal to the viscous resistance of air, and Stokes' law is applicable:

$$
F_{d, S t}=3 \pi \eta_{a} D v \quad[\mathrm{~N}]
$$

The subscript $S t$ is added to clarify that the equation is valid in the Stokes regime only (i.e. the range of situations where flow is laminar). Drops in air experience two forces: the drag force due to air resistance as described above, and gravitation. The latter force is given by

$$
F_{g}=m g=\frac{1}{6} \pi \rho_{d} g D^{3} \quad[\mathrm{~N}]
$$

where $\rho_{d}$ is the density of the drop, and $g$ is the gravitational acceleration $\left(9.81 \mathrm{~m} / \mathrm{s}^{2}\right)$. 
Eventually the forces will balance and the drop falls down at a constant velocity: its socalled sedimentation velocity. From Eqs.(2) and (3) it follows that the sedimentation velocity in the Stokes regime equals:

$$
v_{s, S t}=\frac{\rho_{d} g D^{2}}{18 \eta_{a}} \quad[\mathrm{~m} / \mathrm{s}]
$$

The indices $s$ and $S t$ refer to sedimentation and Stokes regime, respectively. Note that with laminar flow the sedimentation velocity is proportional to the square of the drop diameter. At constant sedimentation, Reynolds' number follows from Eqs.(1) and (4):

$$
\left.\operatorname{Re}_{s, S t}=\frac{\rho_{a} \rho_{d} g D^{3}}{18 \eta_{a}{ }^{2}} \quad \text { [dimensionless }\right]
$$

so $R e_{s, S t}$ will increase very rapidly with increasing drop size. As mentioned before, in the laminar-flow regime Reynolds' number is limited to $R_{e}<0.25$. Thus from Eq.(5) the largest drop that sediments in laminar flow can be derived: $D<50 \mu \mathrm{m}$ (with $\rho_{a}=1.2 \mathrm{~kg} / \mathrm{m}^{3}$, $\left.\eta_{a}=18 \mu \mathrm{Pa} \cdot \mathrm{s}, \rho_{d}=998 \mathrm{~kg} / \mathrm{m}^{3}\right)$.

\subsection{General flow}

Beyond the laminar-flow regime, Stokes' law does not give a good description of the drag force, since the turbulent wake produces an additional drag. The net drag force on an arbitrarily shaped object now tends to become proportional to $v^{2}$ :

$$
F_{d}=C_{d} \frac{1}{2} \rho_{a} A v^{2} \quad[\mathrm{~N}]
$$

where $C_{d}$ is the drag coefficient, which depends on the shape of the object and on Reynolds' number; $A$ is the projected surface area of the object (i.e. its 'shadow') as seen from upstream. For a sphere $A$ equals $(\pi / 4) D^{2}$.

The problem now is to find the relationship between $C_{d}$ and $\mathrm{R} e$. With a proper relation between $C_{d}$ and $R e$ not only the turbulent-flow regime can be covered, but also the laminar-flow regime. Therefore, for low Reynolds' numbers Eq.(6) must equal Stokes' law (Eq.(2)), which results in:

$$
C_{d, S t}=\frac{24 \eta_{a}}{\rho_{a} D v}=\frac{24}{\operatorname{Re}} \quad[\text { dimensionless }]
$$

where the latter equality follows from Eq.(1). 


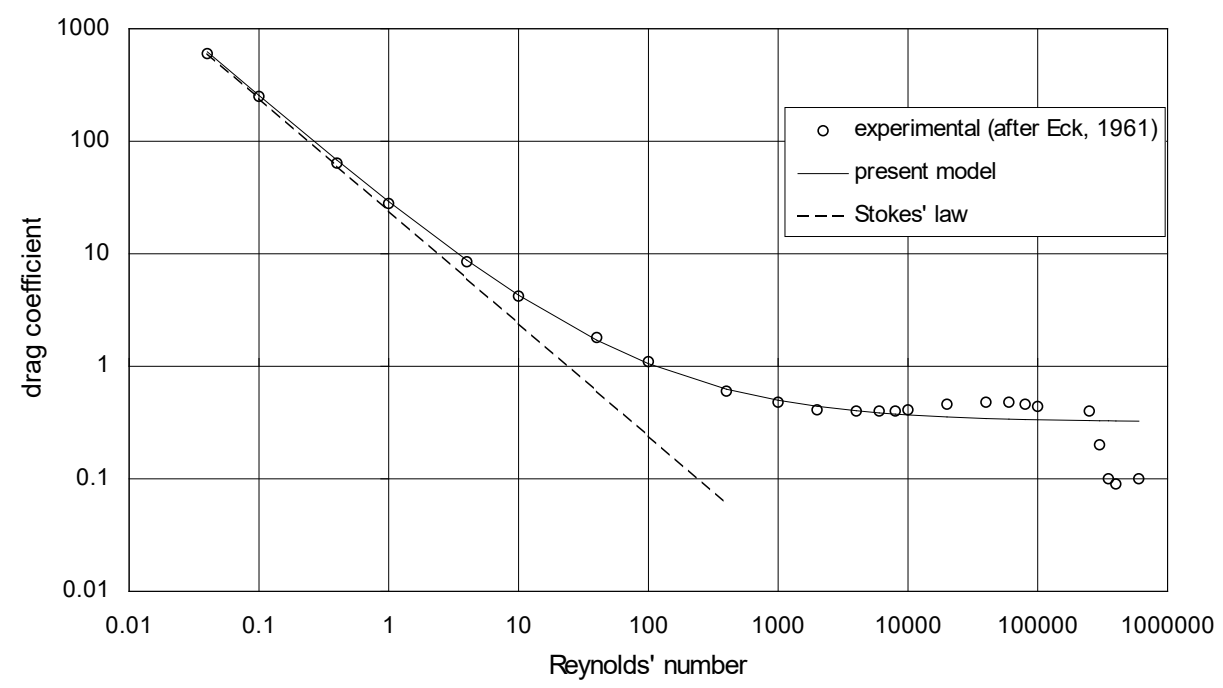

Figure 1. Relationship between drag coefficient $C_{d}$ and Reynolds' number $R e$ for a solid sphere. The present model (solid line; Eq.(8)) fits the experimental data (dots) well up to about $\mathrm{R} e \approx 10^{4}$. For comparison, the result according to Stokes' law is shown (dashed line).

Figuur 1. Verband tussen weerstandscoëfficiënt $C_{d}$ en Reynoldsgetal Re voor een vaste bol. Het buidige model (getroke.en lijn; $V$ gl.(8)) stemt goed overeen met de experimentele data (cirkeltjes) tot ongeveer $\mathrm{Re} \approx 10^{4}$. Ter vergelijking zijn ook de resultaten volgens de wet van Stokes getoond (gestreepte lijn).

Figure 1 shows experimental data for the relationship between $C_{d}$ and $\operatorname{Re}$ for solid spheres (Eck, 1961), as well as the empirical relation to be discussed in the next section. The result according to Stokes' law (dashed line; $C_{d, S t}=24 / R e$ ) clearly shows that it is only valid for small Reynolds' numbers.

\subsection{Empirical model of drag coefficient}

Before trying to fit all experimental data like shown in Figure 1, one should investigate which Reynolds' numbers are relevant for applications of sprays in agriculture. Clearly, very small drops may flow at very low velocity, so no lower boundary for Re should be set. The high-end boundary can be estimated as follows. Assume the largest drop occurring in practice has diameter $1000 \mu \mathrm{m}(=1 \mathrm{~mm})$. If its initial velocity at the outlet of the nozzle is $30 \mathrm{~m} / \mathrm{s}$ (approximately equivalent to a liquid pressure of $700 \mathrm{kPa}$ for conventional nozzles), then the subsequent Reynolds' number is about 2100. Obviously, this is a rather extreme case giving a rough indication of the high-end boundary for practical Reynolds' numbers. 
The following empirical relation was chosen:

$$
C_{d}=\left(\left(\frac{a}{\mathrm{Re}}\right)^{c}+b^{c}\right)^{1 / c} \quad \text { [dimensionless] }
$$

with constants $a=24, b=0.32$ and $c=0.52$. For $R e<<1$ this equation approximates $a / \operatorname{Re}$, which indeed requires $a=24$ to satisfy Stokes' law, according to Eq.(7). Constants $b$ and $c$ follow from optimising the above relation to fit experimental data in the range $\mathrm{R} e=0.25 \ldots 10^{4}$. Figure 1 shows that the present model fits the experimental data well for the given range of Reynolds' numbers. The model not only covers the turbulent-flow regime, but is also applicable to the Stokes regime. For $\mathrm{R} e>10^{4}$ the model deviates from experimental data.

Figure 2 shows the relative error in the calculated drag coefficient with respect to its experimental values. Apart from $\mathrm{Re}=10^{4}$, the error roughly is within $5 \%$ of the experimental value. Figure 2 seems to suggest that the model slightly overestimates the drag coefficient for $R_{e} \leq 10$ and $200 \leq R e \leq 4000$, while it slightly underestimates the drag coefficient for other values of $R e$. Yet an important part of the observed error may be due to the fact that the experimental values are not very accurate, since these are derived from a graph (Eck, 1961, Fig.204).

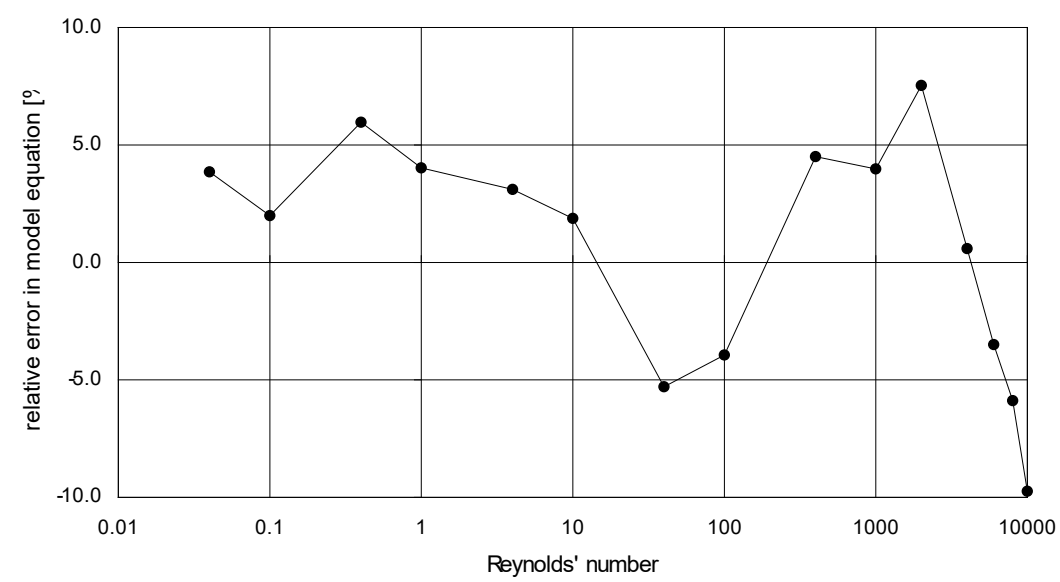

Figure 2. Relative error in calculated drag coefficient with respect to experimental data. The results of the empirical equation appear to fit roughly within $5 \%$ error (excluding $\operatorname{Re}=10^{4}$ ).

Figuur 2. Relatieve fout in de berekende weerstandscoëfficiënt in relatie tot experimentele waarden. De fout in de empirische relatie blijkt ruwweg kleiner dan $5 \%$ te bedragen (met uitzondering van $\mathrm{R} e=10^{4}$ ). 
With $a=24$, the ratio of $C_{d}$ and $C_{d, S t}$ is given by:

$$
\frac{C_{d}}{C_{d, S t}}=\left(1+\left(\frac{b \mathrm{R} e}{24}\right)^{c}\right)^{1 / c} \quad \text { [dimensionless] }
$$

Clearly for positive values of $b$ and $c$, the expression on the left-hand side always is $\geq 1$. One can define the Stokes regime by the range of Reynolds' numbers where $C_{d}$ does not exceed $C_{d, S t}$ by more than $10 \%$. From Eq.(9) the limiting value of $R e$ is determined:

$$
\operatorname{Re}_{S t}<\frac{24}{b}\left(1.1^{c}-1\right)^{1 / c} \approx 0.25 \quad \text { [dimensionless] }
$$

So for $\mathrm{Re}<0.25$ Stokes' law can be used to compute the drag force on a drop, whereas for $\operatorname{Re}>0.25$ Stokes' law underestimates the actual drag force by at least 10\% (and considerably more for $R e>>0.25)$.

\subsection{Sedimentation velocity}

For laminar flows the sedimentation velocity was already given by Eq.(4), which followed from balancing of gravity and drag force. Similarly, extending the sedimentation concept to the non-Stokes flow regime, the forces given by Eqs.(3) and (6) must balance. This results in the following sedimentation velocity:

$$
v_{s}=\sqrt{\frac{4 \rho_{d} g D}{3 \rho_{a} C_{d, s}}} \quad[\mathrm{~m} / \mathrm{s}]
$$

Note that $C_{d, s}$ is the drag coefficient at sedimentation; it depends on Re (by Eq.(8)) and therefore on sedimentation velocity itself (using Eq.(1)). This implies that sedimentation velocity can only be calculated iteratively, using the expression above. Convergence rate depends on drop size, but it can be shown that the sedimentation velocity is accurate within $1 \%$ after 6 iterations at most, and within $0.1 \%$ after 8 iterations at most. Substituting $C_{d}=24 / \mathrm{Re}$ will return Eq.(4), the sedimentation velocity in the Stokes regime, as required.

Figure 3 shows sedimentation velocity as a function of drop diameter for water drops in air, as calculated from the above equation. The dashed line shows the velocity as computed from Eq.(4) if Stokes' law would be valid. Clearly for drop diameters larger than about $50 \mu \mathrm{m}$ Stokes' law is not applicable, and may overestimate the actual velocity considerably. Table 1 shows the sedimentation velocity and corresponding values of Reynolds' number and drag coefficient. 


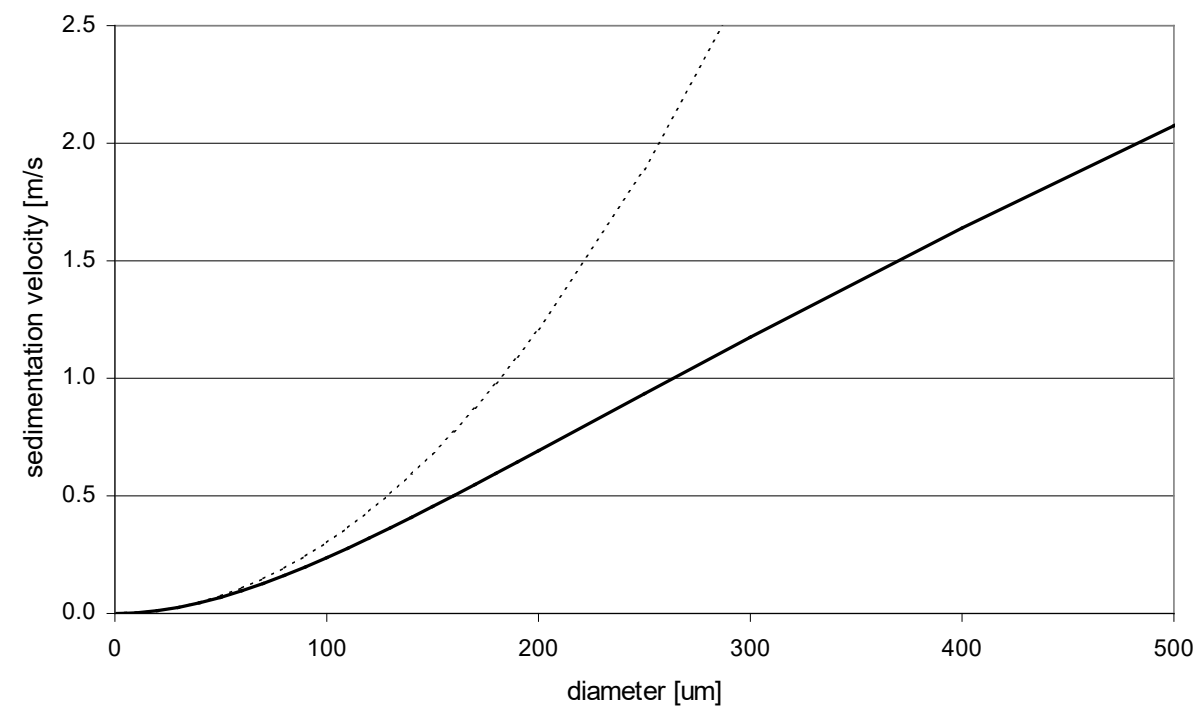

Figure 3. Sedimentation velocity of spherical water drops. Solid line: calculated from present drag model (Eq.(11)); dashed line: velocity according to Stokes' law.

Figuur 3. Sedimentatiesnelheid van bolvormige waterdruppels. Getrokken lijn: berekend met buidige model (Vgl.(11)); gestreepte lijn: snelheid volgens de wet van Stokes.

If one would consider a simple rule of thumb that drops having a sedimentation velocity less than $10 \%$ of average wind speed will be drift-prone, Table 1 shows that for a wind speed of $3 \mathrm{~m} / \mathrm{s}$ drops less than at least $100 \mu \mathrm{m}$ in diameter may contribute to spray drift considerably. Note that only drops larger than approximately $750 \mu \mathrm{m}$ have a sedimentation velocity larger than the assumed wind speed! This may have severe consequences for some spray applications, e.g. spraying fruit trees (see Discussion).

\subsection{Relaxation time}

Due to their mass, drops need a certain time to adapt to sudden changes in local air velocity. Heavier (i.e. larger) drops need more time than lighter (i.e. smaller) drops. The characteristic time scale for adaptation to such changes is the so-called relaxation time $\tau$. This relaxation time is defined by:

$$
\tau=\frac{m v}{F_{d}} \quad[\mathrm{~s}]
$$

The ratio $F_{d} / v$ is known as the friction coefficient. In the Stokes regime this equation yields: 
Table 1. Sedimentation velocity for spherical water drops in air, and corresponding values of Reynolds' number, drag coefficient and relaxation time ${ }^{1}$.

Tabel 1. Sedimentatiesnelheid van bolvormige waterdruppels in lucht, en bijbehorende Reynoldsgetal, weerstandscoëfficiënt en relaxatietijd '.

\begin{tabular}{cccccc}
\hline $\begin{array}{c}D \\
{[\mu \mathrm{m}]}\end{array}$ & $\begin{array}{c}v_{s, S t} \\
{[\mathrm{~m} / \mathrm{s}]}\end{array}$ & $\begin{array}{c}v_{s} \\
{[\mathrm{~m} / \mathrm{s}]}\end{array}$ & $\begin{array}{c}\mathrm{R} e_{s} \\
{[-]}\end{array}$ & $\begin{array}{c}C_{d, s} \\
{[-]}\end{array}$ & $\begin{array}{c}\tau_{s} \\
{[\mathrm{~ms}]}\end{array}$ \\
\hline 10 & 0.00302 & 0.00300 & 0.0020 & 12106 & 0.31 \\
20 & 0.0121 & 0.0118 & 0.016 & 1561 & 1.20 \\
30 & 0.0272 & 0.0260 & 0.052 & 481 & 2.65 \\
40 & 0.0483 & 0.0452 & 0.12 & 213 & 4.61 \\
50 & 0.0755 & 0.0689 & 0.23 & 115 & 7.02 \\
60 & 0.109 & 0.0965 & 0.39 & 70 & 9.83 \\
70 & 0.148 & 0.128 & 0.60 & 47 & 13.0 \\
75 & 0.170 & 0.144 & 0.72 & 39 & 14.7 \\
80 & 0.193 & 0.162 & 0.86 & 33 & 16.5 \\
90 & 0.245 & 0.198 & 1.2 & 25 & 20.2 \\
100 & 0.302 & 0.237 & 1.6 & 19 & 24.2 \\
150 & 0.680 & 0.455 & 4.5 & 7.9 & 46.3 \\
200 & 1.21 & 0.692 & 9.2 & 4.5 & 70.5 \\
250 & 1.89 & 0.935 & 16 & 3.1 & 95.3 \\
300 & 2.72 & 1.18 & 24 & 2.4 & 120 \\
400 & 4.83 & 1.64 & 44 & 1.6 & 167 \\
500 & 7.55 & 2.07 & 69 & 1.3 & 211 \\
750 & 17.0 & 3.05 & 152 & 0.88 & 310 \\
1000 & 30.2 & 3.89 & 259 & 0.72 & 396 \\
\hline
\end{tabular}

${ }^{1}$ With $\rho_{d}=998 \mathrm{~kg} / \mathrm{m}^{3}, \rho_{a}=1.2 \mathrm{~kg} / \mathrm{m}^{3}, \eta_{a}=18 \mu \mathrm{Pa} . \mathrm{s}, \mathrm{g}=9.81 \mathrm{~m} / \mathrm{s}^{2}$. Notation: $v_{s, S t}$ is sedimentation velocity according to Stokes, $v_{s}$ is general sedimentation velocity, $\mathrm{R} e_{s}$ and $C_{d s}$ respectively are corresponding Reynolds' number and drag coefficient at sedimentation, $\tau_{s}$ is relaxation time.

$$
\tau_{S t}=\frac{\rho_{d} D^{2}}{18 \eta_{a}} \quad[\mathrm{~s}]
$$

Note that this relaxation time is proportional to $D^{2}$ but independent of the velocity of the drop. Comparison with Eq.(4) reveals a simple relation between sedimentation velocity and relaxation time:

$$
\tau_{S t}=\frac{v_{s, S t}}{g} \quad[\mathrm{~s}]
$$

Although the previous equation relates the relaxation time to the sedimentation velocity, this relaxation time is valid for all velocities as long as $R_{e}<0.25$. 
For non-Stokes flows, Eq.(12) gives:

$$
\tau=\frac{4 \rho_{d} D}{3 \rho_{a} v C_{d}} \quad[\mathrm{~s}]
$$

In laminar flows, $C_{d}$ approximately is inversely proportional to velocity, and relaxation time tends to be independent of velocity (in fact approximating Eq.(13), as required). In highly turbulent flows, $C_{d}$ is almost independent of velocity and relaxation time approximately is proportional to $D / v$.

Using Eq.(11) the drop size can be eliminated, resulting in:

$$
\tau=\frac{v_{s}^{2} C_{d, s}}{g v C_{d}} \quad[\mathrm{~s}]
$$

Note that the numerator contains velocity and drag coefficient at sedimentation, while the denominator contains their actual values. When the drop reaches its sedimentation velocity, $v=v_{s}$ and $C_{d}=C_{d, s}$, and the last equation simply becomes:

$$
\tau_{s}=\frac{v_{s}}{g} \quad[\mathrm{~s}]
$$

Though this expression looks very similar to Eq.(14), it is only valid at sedimentation velocity, while Eq.(14) is valid for all velocities (as long as the flow is laminar). Table 1 shows relaxation times for various drops at sedimentation velocity. Figure 4 shows an example of the dependence of relaxation time on drop velocity, for a $50 \mu \mathrm{m}$ droplet in air. It shows that the Stokes approximation (Eq.(13)) in fact even for a small drop like this is only valid for very low velocities.

\subsection{Stopping distance}

If a drop is projected horizontally with velocity $v_{0}$ in still air, it slows down and eventually stops (disregarding for the moment a vertical velocity component due to gravitation). The total distance covered horizontally is called 'stopping distance'. Integrating the drag force with respect to time results in the velocity of the drop in time. Integrating this velocity with respect to time gives the path of the drop as a function of time.

Note that the acceleration of the drop (i.e. the rate of change of velocity with time) equals the ratio of net force and mass:

$$
\frac{d v}{d t}=\frac{-F_{d}}{m} \quad\left[\mathrm{~m} / \mathrm{s}^{2}\right]
$$




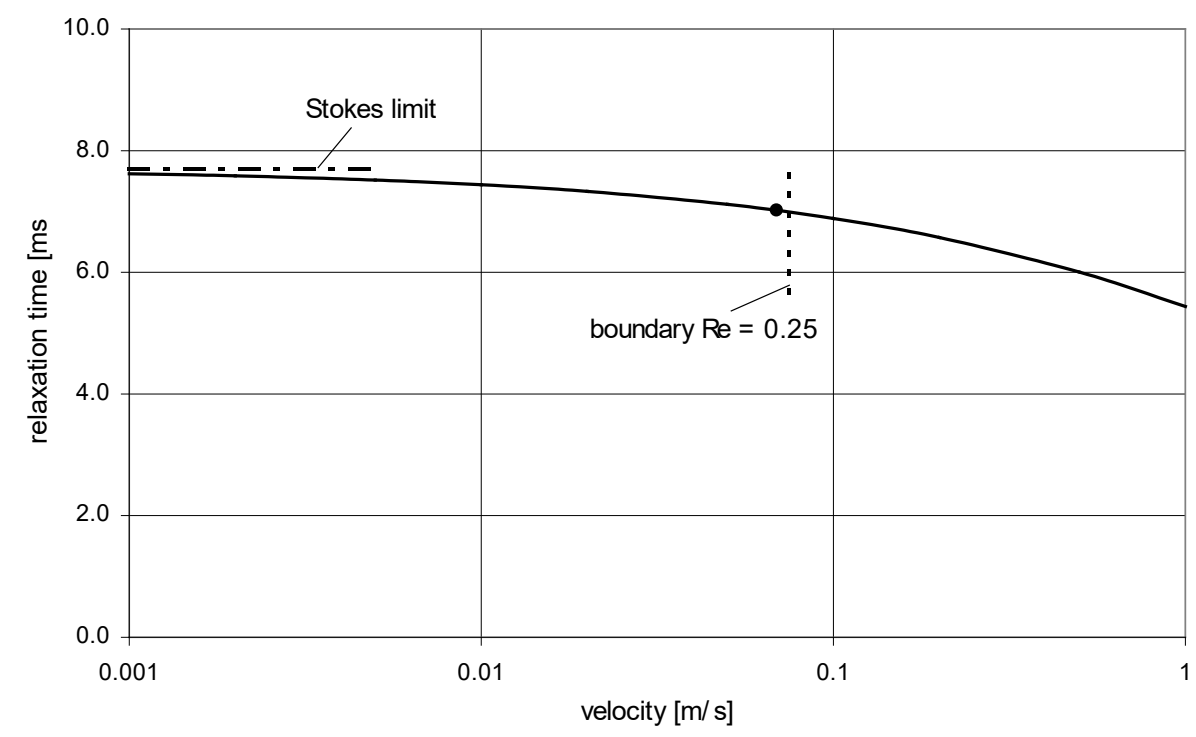

Figure 4. Relaxation time for a drop with diameter $50 \mu \mathrm{m}$, as a function of velocity of the drop (solid line; Eq.(15)). Horizontal dashed line: relaxation time according to Stokes approach $(7.70 \mathrm{~ms}$; Eq.(13)); vertical dotted line: velocity where $R e=0.25$ (i.e. the chosen boundary between laminar and turbulent flow); for this drop the boundary is located at $0.075 \mathrm{~m} / \mathrm{s}$. The black dot indicates stationary sedimentation: $v_{s}=0.0689 \mathrm{~m} / \mathrm{s} ; \boldsymbol{\tau}_{s}=7.02 \mathrm{~ms}$ (Table 1$)$.

Figuur 4. Relaxatietijd voor een druppel met een diameter van $50 \mu \mathrm{m}$ als functie van de druppelsnelheid (getrokken lijn; Vgl.(15)). Horizontale gestreepte lijn: relaxatietijd volgens Stokesbenadering (7.70 ms; Vgl.(13)); verticale gestippelde lijn: snelheid waarbij $\mathrm{Re}=0.25$ (d.i. de gekozen grens tussen laminaire en turbulente stroming); voor deze druppel ligt de grens bij $0.075 \mathrm{~m} / \mathrm{s}$. De zwarte stip verwijst naar stationaire sedimentatie: $v_{s}=0.0689 \mathrm{~m} / \mathrm{s} ; \tau_{s}=7.02 \mathrm{~ms}$ (Tabel 1.).

The minus sign indicates that the drag force tends to slow down the drop (actually it is a deceleration rather than acceleration). Now, with Eq.(6) and $m=\pi \rho_{d} D^{3} / 6$, the so-called 'equation of motion' of the drop is:

$$
\frac{d v}{d t}=\frac{-3 \rho_{a}}{4 \rho_{d} D} v^{2} C_{d} \quad\left[\mathrm{~m} / \mathrm{s}^{2}\right]
$$

With Eq.(15) this equation can be written as:

$$
\frac{d v}{d t}=\frac{-v}{\tau} \quad\left[\mathrm{m} / \mathrm{s}^{2}\right]
$$

Since $\tau$ is not a simple function of $v$, in general this differential equation cannot be solved analytically. However, in the Stokes regime $\tau$ is independent of $v$ and the differential equation can be easily solved, returning an exponential decrease of velocity with time: 


$$
v=v_{0} e^{-t / \tau} \quad[\mathrm{m} / \mathrm{s}]
$$

where $v_{0}$ is the initial velocity (at time $t=0$ ). Integration of this velocity function gives another exponential function for distance with time:

$$
x=v_{0} \tau\left(1-e^{-t / \tau}\right) \quad[\mathrm{m}]
$$

The final value (with time to infinity) is the stopping distance $s_{e}$ (suffix $e$ for 'extended'), and is simply given by:

$$
s_{e, S t}=v_{0} \tau_{S t} \quad[\mathrm{~m}]
$$

When the initial Reynolds' number of the projected drop is larger than 0.25, Eq.(19) can only be solved by numerical integration. As an example, Figure 5 shows the horizontally covered distance with time for a drop (diameter $100 \mu \mathrm{m}$ ) projected with an initial velocity of $10 \mathrm{~m} / \mathrm{s}$. Since the initial value of Reynolds' number is about 67 (from Eq.(1)), the air flow must be turbulent and numerical integration is necessary. The computed stopping distance is approximately $130 \mathrm{~mm}$. At first (about the first $0.05 \mathrm{~s}$ in this case) the drop slows down relatively fast, since the friction coefficient (i.e. $F_{d} / v$ ) is relatively large due to the additional drag by the turbulent wake. When the drop velocity decreases, the wake decreases also and the drop experiences less drag (or rather: the friction coefficient has decreased). If the friction coefficient would not decrease, the stopping distance would be significantly less: about $86 \mathrm{~mm}$ (thin solid line in Figure 5).

Figure 6 shows the stopping distance as a function of drop diameter and initial velocity. The dashed line shows the result if Stokes' law was applicable (for initial velocity $20 \mathrm{~m} / \mathrm{s}$ ). In the Stokes regime, stopping distance is proportional to the square of drop diameter, using Eqs.(13) and (23). For non-Stokes flow, the curves show that stopping distance is less than in an assumed Stokes flow.

In Figure 7 the relaxation time is shown as a function of time, corresponding to the situation of Figure 5. The higher friction coefficient at start means the drop tends to adapt to local air flow faster, and consequently relaxation time is relatively small. When the drop slows down, relaxation time gradually increases and approaches the value for laminar flow (Eq.(13)).

Analogous to Eq.(23), a 'distance-averaged' relaxation time can be defined:

$$
\tau_{\text {avg }}=\frac{s_{e}}{v_{0}} \quad[\mathrm{~s}]
$$

In the above example this averaged relaxation time is approximately $13 \mathrm{~ms}$ (indicated by the dashed line in Figure 7), a value in between of initial relaxation time (8.6 ms) and the value for Stokes-flow $(31 \mathrm{~ms})$. If the drop would experience a drag force corresponding to 
$\tau_{a v g}$ all the time, the stopping distance would be equal to the numerically computed value. The distance-with-time graph would follow the dotted line in Figure 5.

Table 2 gives the stopping distance for various drops projected with initial velocity $10 \mathrm{~m} / \mathrm{s}$ into still air. For comparison also the values are shown if the flow around the drop would be completely laminar, using Eqs.(13) and (23). The ratio of these stopping distances clearly shows that in the non-Stokes regime drops slow down more rapidly. Small drops are able to adapt very quickly to local air flow, as can be seen from the adaptation time $t_{a d p}, s$. This is the time required to cover $95 \%$ of the stopping distance (see also Figure 5). Similarly $t_{a d p, V}$ is the adaptation time to cover $95 \%$ of the change in velocity (i.e. to slow down to $5 \%$ of the initial velocity). In Stokes flow both adaptation times would be equal; in non-Stokes flow it turns out that adaptation of stopping distance takes slightly more time than that of

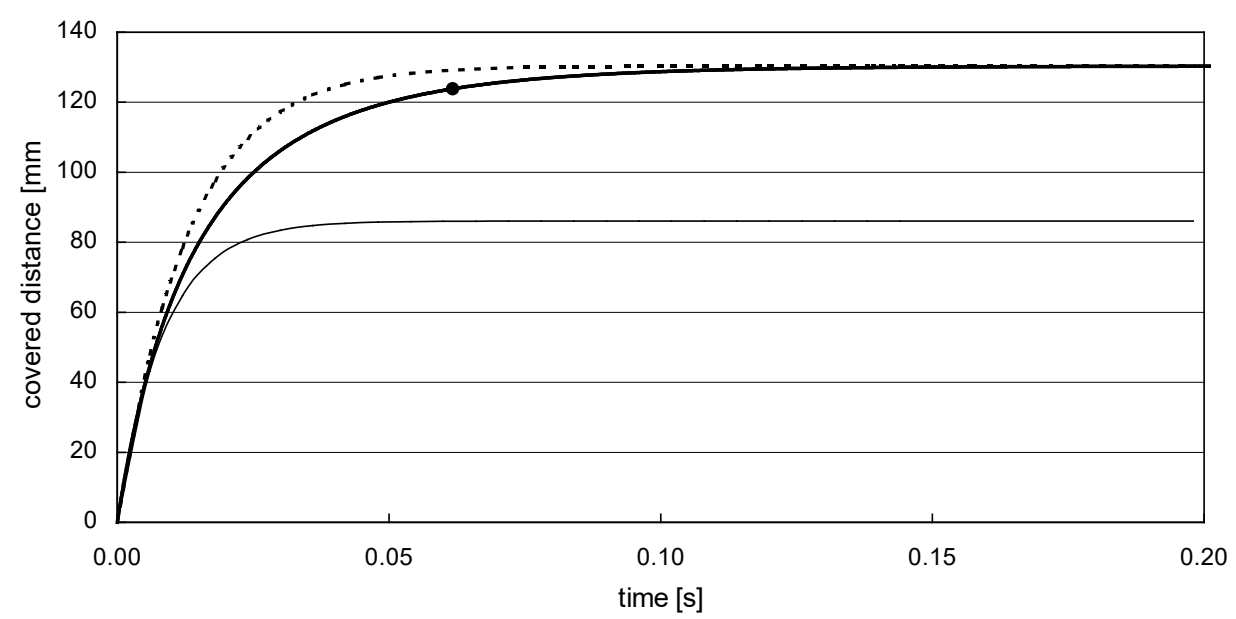

Figure 5. Covered distance of a horizontally projected drop (diameter $100 \mu \mathrm{m}$; initial velocity $10 \mathrm{~m} / \mathrm{s}$ ) in still air, as a function of time. Thick solid line: computed by numerical integration. Thin solid line: exponential curve if the initial friction coefficient (i.e. F/v) would remain throughout. Dotted line: exponential curve if the relaxation time would equal its 'distance-averaged' value (Eq. (24)). Black dot: time $\left(t_{a d p}\right)$ at which $95 \%$ of the stopping distance has been covered (about $62 \mathrm{~ms}$, see Table 2).

Figuur 5. Afgelegde afstand van een horizontaal weggeschoten druppel (diameter $100 \mu \mathrm{m}$; beginsnelheid $10 \mathrm{~m} / \mathrm{s}$ ) in stilstaande lucht en als functie van de tijd. Dikke getrokken lijn: berekend via numerieke integratie. Dunne getrokken lijn: exponentiële curve als de beginwaarde van de frictiecoëfficiënt (d.i. F/v) zou blijven bestaan. Gestippelde curve: exponentiële curve als de relaxatietijd de 'afstandsgemiddelde' waarde zou hebben (Vgl.(24)). Zwarte stip: tijd (tadp) waarbij 95\% van de 'stopafstand' is afgelegd (ca. $62 \mathrm{ms,}$ zie Tabel 2). 


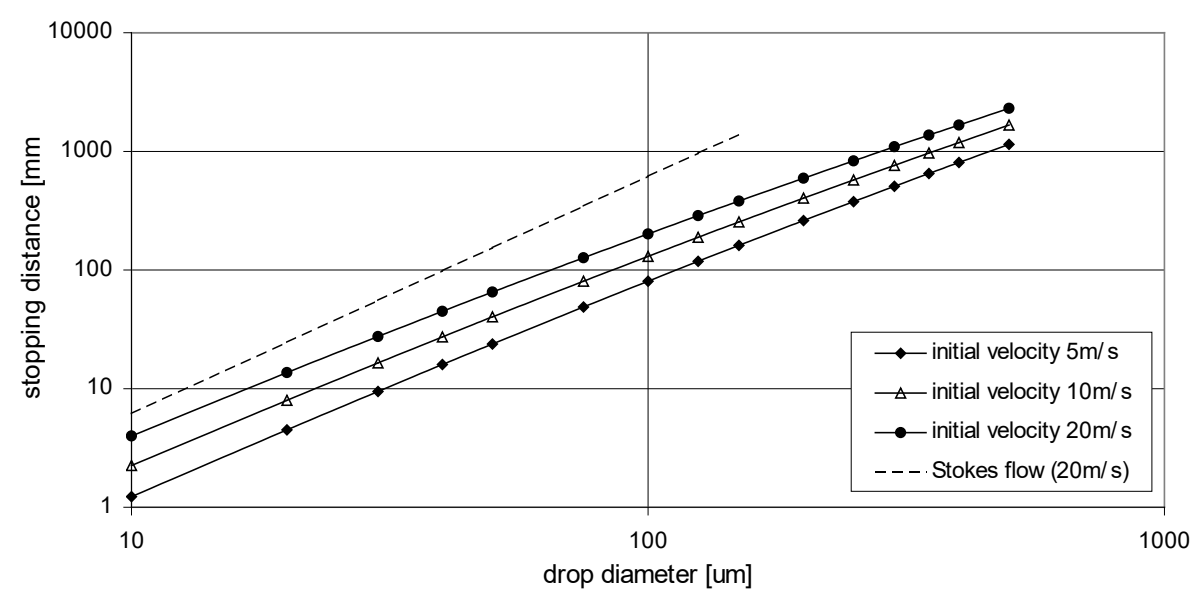

Figure 6. Stopping distance as a function of drop diameter, for several initial velocities. Dashed line: stopping distance for initial velocity $20 \mathrm{~m} / \mathrm{s}$, if Stokes law would be applicable (using Eqs.(13) and (23)).

Figuur 6. 'Stopafstand' als functie van druppeldiameter voor diverse beginsnelheden. Gestreepte lijn: stopafstand bij beginsnelheid $20 \mathrm{~m} / \mathrm{s}$ als de wet van Stokes toegepast rou mogen worden (met behulp van Vgl.(13) en (23)).

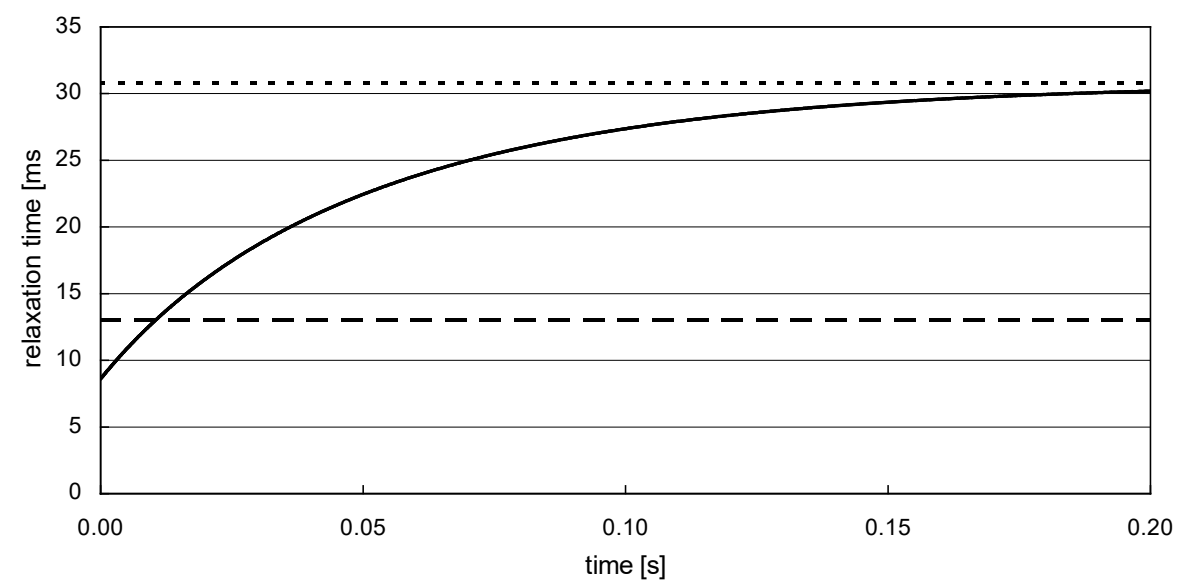

Figure 7. Relaxation time as a function of time, for a horizontally projected drop (diameter $100 \mu \mathrm{m}$; initial velocity $10 \mathrm{~m} / \mathrm{s}$ ) in still air. Solid line: computed by numerical integration. The dashed line indicates the average relaxation time which gives the same stopping distance. The dotted line indicates the relaxation time according to Stokes.

Figuur 7. Relaxatietijd als functie van de tijd voor een horizontaal weggeschoten druppel (diameter $100 \mu \mathrm{m}$; beginsnelheid $10 \mathrm{~m} / \mathrm{s}$ ) in stilstaande lucht. Getrokken lijn: berekend via numerieke integratie. De gestreepte lijn verwijst naar de gemiddelde relaxatietijd die dezelfde stopafstand oplevert. De gestippelde lijn verwijst naar de relaxatietijd volgens Stokes. 
Table 2. Stopping distance as a function of drop diameter; initial velocity $10 \mathrm{~m} / \mathrm{s}^{1}$. Computed for non-Stokes flow $\left(s_{e}\right)$ and if Stokes law would be valid $\left(s_{e, S t}\right)$. Included: distance-averaged relaxation time $\tau_{\text {avg }}$, and adaptation times $t_{\text {adp }, s}$ and $t_{a d p, V}$ to cover $95 \%$ of the stopping distance and velocity change, respectively.

Tabel 2. Stopafstand als functie van de druppeldiameter; beginsnelheid $10 \mathrm{~m} / \mathrm{s}^{1}$. Berekend voor niet-Stokes stromingen $\left(s_{e}\right)$ en als de wet van Stokes toegepast zou worden $\left(s_{e}, S t\right)$. Verder: afstandsgemiddelde relaxatietijd $\tau_{\text {avg, }}$, en aanpassingstijden $t_{\text {atp, }}$ en $t_{\text {alp }, V}$ om $95 \%$ van resp. de stopafstand en de snelheidsverandering te overbruggen.

\begin{tabular}{ccccccc}
\hline $\begin{array}{c}D \\
{[\mu \mathrm{m}]}\end{array}$ & $\begin{array}{c}s_{e} \\
{[\mathrm{~mm}]}\end{array}$ & $\begin{array}{c}s_{e} S t \\
{[\mathrm{~mm}]}\end{array}$ & $\begin{array}{c}s_{e} / s_{e}, S t \\
{[-]}\end{array}$ & $\begin{array}{c}\tau_{\text {avg }} \\
{[\mathrm{ms}]}\end{array}$ & $\begin{array}{c}t_{\text {adp }, S} \\
{[\mathrm{~ms}]}\end{array}$ & $\begin{array}{c}t_{\text {adp }, V} \\
{[\mathrm{~ms}]}\end{array}$ \\
\hline 10 & 2.3 & 3.1 & 0.73 & 0.23 & 0.79 & 0.71 \\
20 & 8.0 & 12.3 & 0.65 & 0.80 & 2.97 & 2.60 \\
30 & 16.5 & 27.7 & 0.59 & 1.65 & 6.43 & 5.45 \\
40 & 27.3 & 49.3 & 0.55 & 2.73 & 11.1 & 9.15 \\
50 & 40.3 & 77.0 & 0.52 & 4.03 & 16.9 & 13.6 \\
75 & 80.5 & 173 & 0.46 & 8.05 & 36.1 & 27.8 \\
100 & 130 & 308 & 0.42 & 13.0 & 61.7 & 45.7 \\
125 & 188 & 481 & 0.39 & 18.8 & 93.3 & 66.8 \\
150 & 254 & 693 & 0.37 & 25.4 & 131 & 90.8 \\
200 & 403 & 1232 & 0.33 & 40.3 & 222 & 146 \\
250 & 573 & 1925 & 0.30 & 57.3 & 335 & 211 \\
300 & 762 & 2772 & 0.27 & 76.2 & 469 & 283 \\
400 & 1187 & 4928 & 0.24 & 119 & 793 & 446 \\
500 & 1663 & 7701 & 0.22 & 166 & 1190 & 631 \\
\hline
\end{tabular}

${ }^{1}$ With $\rho_{d}=998 \mathrm{~kg} / \mathrm{m}^{3}, \rho_{a}=1.2 \mathrm{~kg} / \mathrm{m}^{3}, \eta_{a}=18 \mu \mathrm{Pa} . \mathrm{s}, \mathrm{g}=9.81 \mathrm{~m} / \mathrm{s}^{2}$.

velocity change. For drops less than $125 \mu \mathrm{m}$ in diameter adaptation time (regarding distance) is less than $0.1 \mathrm{~s}$. Even for a drop as large as $500 \mu \mathrm{m}$ adaptation time is only about $1 \mathrm{~s}$. Comparing adaptation time with relaxation time at sedimentation (Table 1, page 18) shows that for drops in the range $50-200 \mu \mathrm{m}$ and initial velocity $10 \mathrm{~m} / \mathrm{s}, t_{a d p, s}$ is about 2.5-3 times $\tau_{s}$, and $t_{a d p, V}$ is about 2 times $\tau_{s}$.

\subsection{Impaction on spherical targets}

The above sections were not dealing with practical applications and may seem rather remote. One important application is the sampling of drops in an air stream. The use of passive collectors is a common method. However, since a collector is an obstructing object, air will float around it. Drops will try to follow the air stream, but due to their mass they cannot succeed all. Some drops will impact on the collector, others will float around it. The 
ratio of the number of impacted drops and the total number of drops streaming towards the collector, is called impaction efficiency $E$.

May and Clifford (1967) studied the impact of drops in an air stream onto fixed objects with various shapes. They concluded from their experiments that impaction efficiency is only a function of object shape and the so-called 'impaction parameter' $P$, which is defined as the ratio of stopping distance of the drops and the characteristic size of the object (i.e. diameter if the object is a sphere). For a spherical collector with diameter $D_{c}$ the impaction parameter is defined by:

$$
P=\frac{s_{e}}{D_{c}} \quad[-]
$$

The stopping distance was defined in Section 2.7 for a drop projected with initial velocity $v_{0}$ in still air. In the case of impact on a fixed object, the initial velocity of the drop essentially is the average air velocity. Clearly the situation is not 'still air', rather the collector has zero velocity. In Figure 8 the relation between impaction efficiency and impaction parameter is shown for a solid spherical object. It turns out that the dots can be fitted very well by a cubic function of the logarithm of the impaction parameter:

$$
E=-0.35(\ln P)^{3}-1.74(\ln P)^{2}+22 \ln P+59 \quad[\%]
$$

Obviously this equation has to be truncated for efficiencies below zero and above $100 \%$.

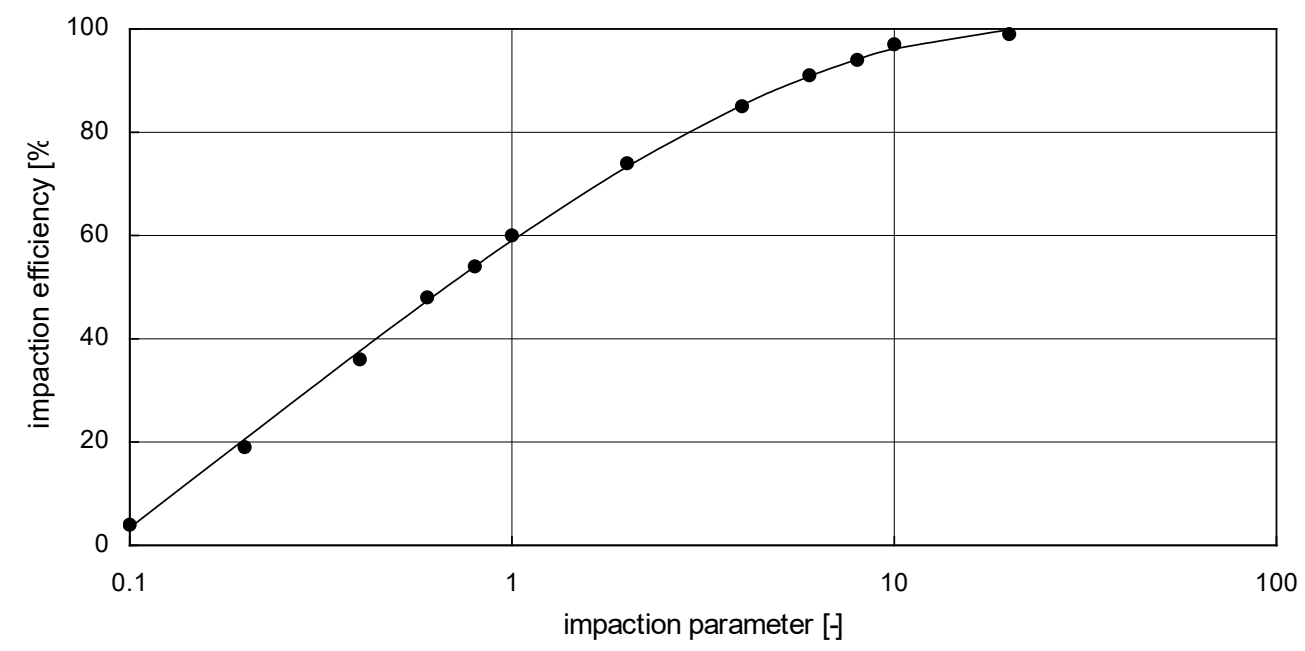

Figure 8. Relation between impaction efficiency and impaction parameter for a solid sphere. Dots: derived from May and Clifford (1967, their Fig.5). Line: empirical fit to the dots (Eq.(26)).

Figuur 8. Verband tussen 'botsingsefficiëntie' en 'botsingsparameter' voor een vaste bolvormig object. Stippen: afgeleid van May en Clifford (1967, bun Figuur 5). Lijn: empirische fit aan de stippen (Vgl.(26)). 
From this empirical equation, and the impaction parameter from Eq.(25), the efficiency of a spherical collector to catch drops out of an air stream is computed as a function of drop diameter and air velocity. The dots in Figure 9 show impaction efficiencies computed this way, for a solid spherical collector $(0.08 \mathrm{~m}$ diameter, which is the size of the drift sampling spheres currently used at IMAG) and various drop sizes and air velocities. Each dot is the result of a relatively large set of calculations, since stopping distance must be computed iteratively. Therefore, for practical purposes it is convenient to use an empirical model to estimate impaction efficiency for arbitrary drop size and air velocity. A cubic equation appears to fit the dots in Figure 9 well:

$$
E=100 \cdot\left[1-\frac{\delta}{6}\left(\frac{y^{3}}{\delta^{3}}-3 \frac{y}{\delta}+2\right)\right] \quad[\%]
$$

where $y$ is a relative measure of drop diameter $(D)$, and $\delta$ is a constant, respectively defined as:

$$
\begin{aligned}
& y=\ln D-\ln D_{0} \\
& \delta=\ln D_{m}-\ln D_{0}
\end{aligned}
$$

$D_{m}$ is the drop diameter at which impaction efficiency is essentially $100 \%$. $D_{0}$ is the diameter where the curve has its bending point. Though $D_{0}$ has no direct physical meaning, it appears to indicate roughly the drop size below which impaction efficiency is zero. Both $D_{m}$ and $D_{0}$ depend on velocity of the air stream; they can be described well by a power-law function:

$$
\begin{array}{ll}
D_{m}=1324 w^{-0.4072} & {[\mu \mathrm{m}]} \\
D_{0}=38.01 w^{-0.5961} & {[\mu \mathrm{m}]}
\end{array}
$$

where $w$ is air velocity in $\mathrm{m} / \mathrm{s}$. The empirical fit in Figure 9 is computed using these equations ((27)-(31)) for drop diameter range 10-500 $\mu \mathrm{m}$ and air velocity range $0.1-5 \mathrm{~m} / \mathrm{s}$, which covers most practical cases for agricultural sprays. Within these ranges, the deviation from the directly calculated efficiencies (i.e. the dots in Figure 9 ) is within $1 \%$ of the efficiency scale. Note that Eqs. (30) and (31) are valid for spheres with diameter $0.08 \mathrm{~m}$ only. For spheres of other size the constants have to be adjusted empirically.

\subsection{Trajectory of a single drop in a cross wind}

Another application of the above theory is the calculation of the trajectory of a drop projected vertically downward into a horizontally moving air stream. Clearly this is a rather simple model of what happens during spraying with a boom sprayer. Yet it gives an idea of 


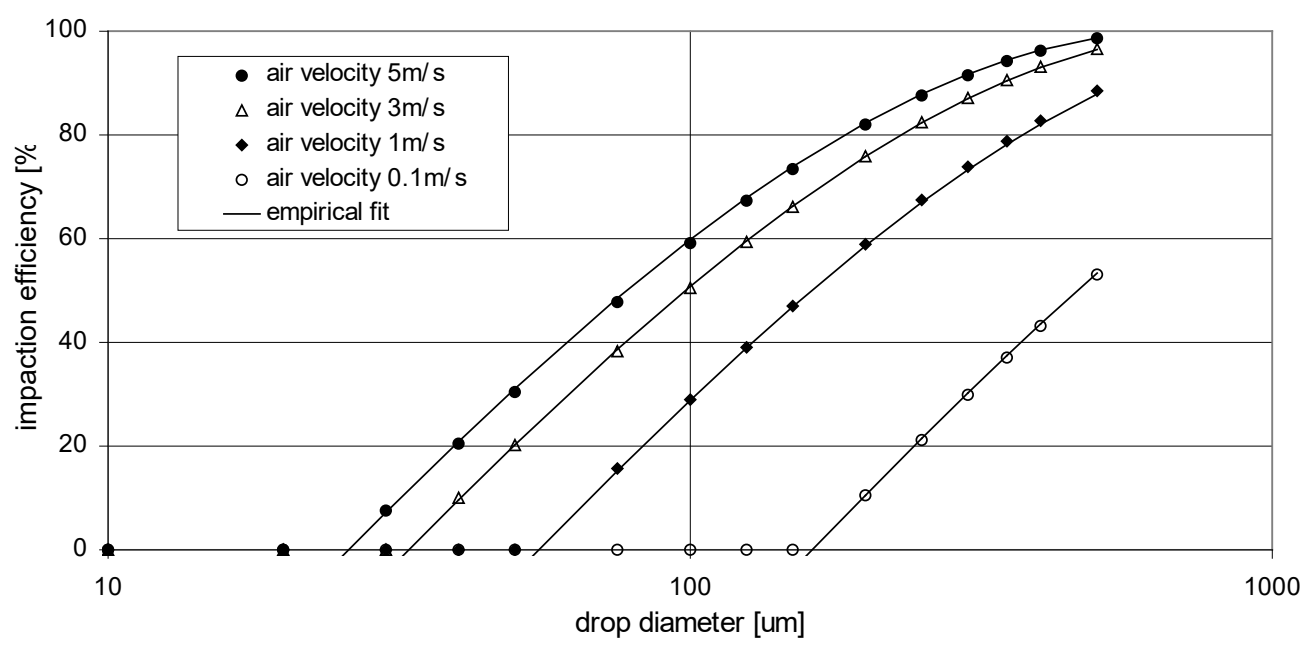

Figure 9. Impaction efficiency as a function of drop diameter and wind velocity, for a solid spherical collector (0.08 m diameter). Dots: computed using Eqs.(25) and (26). Lines: empirical fit of the dots (Eqs.(27)-(31)).

Figuur 9. Botsingsefficiëntie als functie van druppeldiameter en windsnelheid voor een dichte bolvormige collector (0.08 m diameter). Stippen: berekend met behulp van Vgl.(25) en (26). Lijnen: empirische fits aan de stippen (Vgl.(27)-(31)).

what can be expected for drops of certain sizes in situations not too different from real practice.

Two aspects are important in determining the trajectory of a drop projected vertically downward. Firstly, the stopping distance is a measure of the distance the drop can penetrate into the air stream, before it has lost its own momentum and it is at the mercy of wind and gravity. Secondly, after this transient time of deceleration, the sedimentation velocity determines (together with wind speed) the downward angle of the next part of the trajectory.

A small drop has only a short stopping distance, while its sedimentation velocity is small. Therefore the trajectory of such a drop will make a sharp bend from vertical to horizontal, relatively close to the point of release (i.e. the nozzle); the further part of the trajectory will be almost horizontal. A large drop, having a large stopping distance and a relatively high sedimentation velocity, will have a trajectory that bends much farther downward. Besides, the trajectory beyond the bend will have a clear slope downward. Figure 10 shows the trajectories for drops between 50 and $500 \mu \mathrm{m}$ in diameter, starting at a vertical velocity of $20 \mathrm{~m} / \mathrm{s}$ in the upper left corner of the graph (simulated with IDEFICS v3.2). Wind speed is $3 \mathrm{~m} / \mathrm{s}$ (independent of height in this example). The effect of turbulence or evaporation is excluded. The graph shows that small drops $(50,100 \mu \mathrm{m})$ may stay airborne for a long 


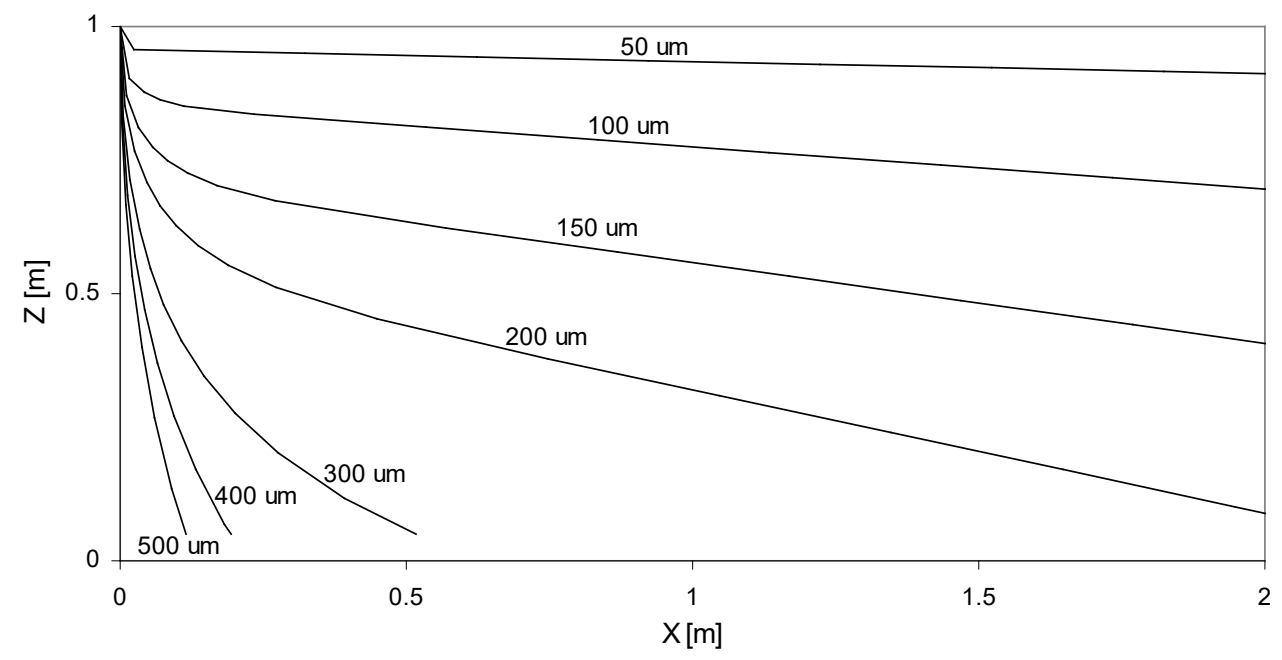

Figure 10. Trajectories of drops projected downward at initial velocity $20 \mathrm{~m} / \mathrm{s}$, into a constant horizontal air stream of $3 \mathrm{~m} / \mathrm{s}$ (simulated using IDEFICS v3.2). Parameter: droplet diameter.

Figuur 10. Banen van druppels die met een beginsnelheid van $20 \mathrm{~m} / \mathrm{s}$ verticaal weggeschoten worden in lucht met een constante horizontale snelheid van $3 \mathrm{~m} / \mathrm{s}$ (via simulatie met IDEFICS v3.2). Parameter: druppeldiameter.

time; medium-sized drops $(150-300 \mu \mathrm{m})$ may deposit at a significant distance downwind; large drops $(400-500 \mu \mathrm{m})$ show only slight horizontal displacement. Especially the medium-sized drops seem to contribute significantly to drift. However, the simulations in this example differ on several important aspects from a real application. The major differences that affect droplet trajectories are the logarithmic wind profile, and velocity of entrained air. Due to the wind profile (i.e. decreased wind speed closer to the ground) sloping trajectories will slightly curve downward. Entrained air is induced by high-speed drops in the spray cone near the nozzle. This vertical air flow effectively drags the drops much farther downward than their stopping distance, resulting in trajectories not as 'bad' as Figure 10 seems to show.

\subsection{Discussion}

In this chapter some characteristics of the flow of spherical particles in air are described. The drag coefficient $C_{d}$ is related to Reynolds' number $R e$ through a single function, for Reynolds' numbers ranging from practically zero up to $10^{4}$. For very low Reynolds' numbers $(\mathrm{Re}<0.25)$, Stokes' law of viscous drag is applicable, which results in simplified equations for several quantities. 
In chemical crop protection, the range of drop sizes and occurring velocities gives Reynolds' numbers often beyond the Stokes regime, but always $\mathrm{Re}<<10^{4}$.

Drops left alone in still air will eventually fall down at their sedimentation velocity, which depends on drop size. With respect to spray drift, droplet movement is primarily horizontal. Clearly one must conclude that sedimentation velocity of the drifting drops is much less than average wind speed. As a rule of thumb drops having a sedimentation velocity less than $10 \%$ of average wind speed can be considered drift-prone. For a wind speed of $3 \mathrm{~m} / \mathrm{s}$ this rule implies that drops with diameters up to at least $100 \mu \mathrm{m}$ may contribute to spray drift considerably (see Table 1). Other factors that may affect the trajectories of drops are nozzle type (through spray cone angle and the phenomenon of 'entrained air'), liquid pressure (determining initial velocity of the drops), height of the sprayer boom above the crop, presence of air-assistance or shields, and natural air turbulence. However, though the chemical formulation of the spray may affect drop size spectrum, it will hardly affect droplet trajectories (in fact only if mass density of the formulation differs from that of water).

Only for very large drops (typically $>750 \mu \mathrm{m}$ ) sedimentation velocity is larger than wind speed. In conventional field application, however, the initial velocity of drops is much higher than their sedimentation velocity (typically $10-30 \mathrm{~m} / \mathrm{s}$, for commonly used flat fan nozzles at liquid pressure roughly $150-600 \mathrm{kPa}$ ). Since the relaxation time for large drops is relatively high, such drops will impact onto the crop without considerable deceleration. For medium-sized drops (100-750 $\mu \mathrm{m}$, as far as sedimentation is considered), drops projected downward with large velocity will roughly cover their stopping distance first, then start to sediment freely. Using the numerical method of Section 2.7, it can be shown that drops with diameter $200 \mu \mathrm{m}$ and initial velocity $20 \mathrm{~m} / \mathrm{s}$ have a stopping distance of almost $0.6 \mathrm{~m}$. If boom height is $0.5 \mathrm{~m}$ above the crop, they will probably impact onto the crop before free sedimentation starts.

The above considerations show that, with respect to the physics of sedimentation, particularly drops ranging from 100 to $200 \mu \mathrm{m}$ are crucial for spray drift. Smaller drops will probably drift no matter what, while larger drops will impact onto the crop. Whether drops in the intermediate range will contribute to spray drift or impact onto the crop, largely depends on other aspects such as boom height, wind speed, and presence of air-assistance.

Regarding impaction efficiency in Section 2.8, it is assumed that the collectors are solid spheres. In spray drift experiments at IMAG, though, collectors for sampling airborne spray drift are more like tangled balls of synthetic threads. The surface is not smooth at all and air (including airborne drops) streaming towards a collector will probably penetrate it slightly. Inside the collector, the impact of drops is quite a different process. One has to deal with a relatively slow air stream, while the obstructing objects are long, curved, thin 
strips. Overall impaction efficiency for such a collector will be larger than that of a solid sphere, yet to what extent impaction efficiency increases is still unknown. So far an impaction efficiency calculated using the presented theory can be considered as a lower boundary.

The theoretical and empirical results of this chapter can be useful for several purposes. At present, one important application is its implementation in the IDEFICS simulation model for spray drift of conventional boom sprayers. In IDEFICS droplet trajectories through air are computed using local drag coefficients and relaxation times as described in this chapter.

The presented theory is not limited to field sprayers. In fact it can be used for all spray application techniques, though typical values given in examples above should be reexamined for such applications. E.g. spraying fruit crops often involves horizontally or even upwardly directed sprays. In that case medium-sized drops may cover their stopping distance before impacting on a target or the ground. Therefore drops in the range 200-500 $\mu \mathrm{m}$, though not actually drifting horizontally but floating down at an angle, may still be hazardous for the surrounding area (e.g. ground surface adjacent to the fruit crop).

In a wider perspective, the general nature of the relations in this study is not limited to water droplets, but the theory can be applied to all processes where small spherical particles in a homogeneous solvent (air or liquid) are involved. 


\section{In-flight evaporation of drops}

\subsection{Introduction}

It is a common physical phenomenon that liquids evaporate. Depending on ambient temperature and vapour pressure, each liquid (but also many solids) will show more or less evaporation behaviour (see Table 3). In chemical crop protection, evaporation of solvent (usually water) and solute (dissolved or suspended chemicals) is an important issue, both during and after application. In all practical spray applications the vapour pressure of the solute is much less than that of water, and consequently the evaporation rate of the solute will be much lower than that of water. Therefore it seems reasonable to assume that spray drops in air will loose their water content rather rapidly. Subsequently the remaining waterfree particle will evaporate very slowly with respect to the evaporation of water. In the spray drift model IDEFICS (Holterman et al., 1997) it was assumed that only water would evaporate during application and all solutes would be chemically inert. This seems reasonable for short distance downwind drift (down to typically 10-20 m from the edge of the crop).

A water drop falling through air, or floating in air, is subject to evaporation and will decrease in size. During a certain (but relatively short) transient time, the drop cools down due to evaporation, until it reaches its 'wet-bulb' temperature. At the same time, a thin layer of saturated vapour has formed around the drop. Since the temperature of the drop is lower than that of the ambient air, heat flows towards the drop and 'feeds' the evaporation process.

The physical model behind this process has been described several decades ago (Ranz and Marshall, 1952a, 1952b; Goering et al., 1972; Williamson and Threadgill, 1974). In this chapter it will be shown that the physical model can be simplified considerably for aqueous sprays in air. The simplified model has a practical application in the spray drift model IDEFICS.

Lefebvre (1989) showed that $D^{2}$ decreases linearly with time, for heated oil drops with $D>300 \mu \mathrm{m}$. Hartley and Graham-Bryce (1980) mentioned the following simple relationship between drop diameter $D$ and lifetime:

$$
t_{\text {life }}=\frac{D^{2}}{78 \Delta T} \quad[\mathrm{~s}]
$$

where $\Delta T$ is the difference between dry-bulb and wet-bulb temperature. In this chapter it will be shown that these relations are too simple to be used as a general model of evaporation of water drops in air. 
Table 3. Physical properties of some solvents and pesticides.

Tabel 3. Physische eigenschappen van enkele oplosmiddelen en pesticiden.

\begin{tabular}{cccccc}
\hline Substance & M & $\begin{array}{c}\text { Density } \\
{\left[25^{\circ} \mathrm{C}\right]} \\
{\left[\mathrm{kg} / \mathrm{m}^{3}\right]}\end{array}$ & $\begin{array}{c}\text { SVP a } \\
{\left[20^{\circ} \mathrm{C}\right]} \\
{[\mathrm{Pa}]}\end{array}$ & $\begin{array}{c}\text { Boiling point } \\
(1 \mathrm{~atm}) \\
{\left[{ }^{\circ} \mathrm{C}\right]}\end{array}$ & Authorized use in the Netherlands \\
\hline Water & 18.0 & 998 & 2340 & 100 & 78.5 \\
Ethanol & 46.1 & 789 & 5380 & 3.6 & $\begin{array}{c}\text { Insecticide, acaricide: } \\
\text { Methylbromide }\end{array}$ \\
1,3-dichloropropene & 111.0 & 1214 & 3700 & $104-112$ & $\begin{array}{c}\text { Nematicide: soil fumigation, } \\
\text { (no longer authorized) }\end{array}$ \\
Methyl-isothiocyanate ${ }^{\mathrm{c}}$ & 107.2 & $1069 \mathrm{~d}$ & 2700 & 118 & $\begin{array}{c}\text { Fungicide, nematicide: } \\
\text { soil fumigation }\end{array}$ \\
Dichlorvos & 221.0 & $1425 \mathrm{e}$ & $2.1 \mathrm{f}$ & 234 & $\begin{array}{c}\text { Insecticide (fumigant action) } \\
\text { few applications authorized } \\
\text { Parathion }\end{array}$ \\
Fipronil & 291.3 & 1270 & 0.00089 & 150 & $\begin{array}{c}\text { Contact insecticide, acaricide } \\
\text { (no longer authorized) }\end{array}$ \\
\hline
\end{tabular}

Sources: CRC Handbook of Chemistry and Physics (Weast, 1986); The Pesticide Manual (Tomlin, 1997)

a SVP: saturated vapour pressure; "liquid, $0^{\circ} \mathrm{C} ;{ }^{\circ}$ usually applied as its sodium salt metham-sodium, which dissociated in bumid soil; density at $37^{\circ} \mathrm{C} ;{ }^{\circ}$ density at $20^{\circ} \mathrm{C} ;{ }^{f} S V P$ at $25^{\circ} \mathrm{C}$ 


\subsection{Decrease of drop diameter with time}

\subsubsection{General derivation}

The rate of decrease of the diameter $D$ of a spherical drop in air due to evaporation can be described by (Williamson and Threadgill, 1974):

$$
\frac{d D}{d t}=\frac{-4 M_{L} D_{v, f}}{D \rho_{L} R T_{f}} \Delta p\left(1+0.276 R e^{1 / 2} S c^{1 / 3}\right) \quad[\mathrm{m} / \mathrm{s}]
$$

where $M_{L}$ is molecular weight of the evaporating liquid (water: $0.018 \mathrm{~kg} / \mathrm{mole}$ ), $\rho_{L}$ is the density of the liquid, $D_{v, f}$ is the average diffusion coefficient for vapour molecules in the saturated film around the drop, $T_{f}$ is the average absolute temperature in that film, $R e$ is Reynolds' number, $S_{c}$ is Schmidt's number, $\Delta p$ is the difference between the vapour pressure near the drop and that in the ambient atmosphere, and $R$ is the gas constant $\left(=8.3144 \mathrm{~J} \mathrm{~mol}^{-1} \mathrm{~K}^{-1}\right)$.

Reynolds' number and Schmidt's number should both be evaluated for the saturated film, i.e. at temperature $T_{f}$. Reynolds' number is calculated from Eq.(1):

$$
\operatorname{Re}=\frac{\rho_{a, f} D v}{\eta_{a, f}} \quad[-]
$$

where $v$ is velocity of the drop relative to the surrounding air; $\rho_{a, f}$ is air density at temperature $T_{f} ; \eta_{a, f}$ is air viscosity at temperature $T_{f}$. Schmidt's number is a dimensionless quantity relating viscous transport of material to diffusive transport; it is calculated from:

$$
S_{c}=\frac{\eta_{a, f}}{\rho_{a, f} D_{v, f}} \quad[-]
$$

Combining Eqs.(33), (34) and (35), and assuming that only $D$ and $v$ are time dependent, one yields:

$$
\frac{d D}{d t}=\frac{-a}{D}(1+b \sqrt{D v}) \quad[\mathrm{m} / \mathrm{s}]
$$

where $a$ and $b$ are constants depending only on ambient conditions and liquid properties:

$$
\begin{aligned}
& a=\frac{4 M_{L} D_{v, f} \Delta p}{\rho_{L} R T_{f}} \quad\left[\mathrm{~m}^{2} / \mathrm{s}\right] \\
& b=0.276\left(\frac{\rho_{a, f}}{\eta_{a, f} D_{v, f}^{2}}\right)^{1 / 6} \quad\left[\mathrm{~m}^{-1} \mathrm{~s}^{1 / 2}\right]
\end{aligned}
$$

Often evaporation is described by the so-called evaporation constant $K$, defined by 


$$
K=-\frac{d D^{2}}{d t} \quad\left[\mathrm{~m}^{2} / \mathrm{s}\right]
$$

For relatively large drops $(>300 \mu \mathrm{m})$ experiments showed that $K$ indeed is approximately constant (Ranz and Marshall, 1952b; Lefebvre, 1989), only depending on temperature, relative humidity and physical properties of the liquid (heat of vaporisation) and air (thermal conductivity). In fact proclaiming that $K$ is a constant means that $K$ is not dependent on drop size, drop velocity or time. However, combining Eqs.(36) and (39) gives:

$$
K=-2 D \frac{d D}{d t}=2 a(1+b \sqrt{D v}) \quad\left[\mathrm{m}^{2} / \mathrm{s}\right]
$$

Clearly this equation shows that $K$ is not a constant, since there is a dependence on drop size and velocity. Since $D$ and $v$ change with time, $K$ will change also, implying that the term evaporation 'constant' is not fully covering its actual physical behaviour. Therefore it seems more appropriate to denote $K$ as evaporation rate instead.

Most of the required parameters (densities of air and water, viscosity of air, vapour diffusion coefficient, absolute temperature) vary with temperature only slightly in the range of common ambient temperatures (see Appendix D). An important exception is the vapour pressure difference $\Delta p$. This pressure difference acts as the 'driving force' for transport of vapour away from the droplet surface. It can be related to saturated vapour pressures at ambient and wet-bulb temperature ( $T$ and $T_{w}$, respectively; see Appendix $C$ ):

$$
\Delta p=p_{s a t, f}-p=\gamma\left(T-T_{w}\right) \quad[\mathrm{Pa}]
$$

where $p_{\text {sat } f}$ is the vapour pressure near the surface of the drop, and $p$ is vapour pressure in ambient air; $\gamma$ is approximately constant $(\sim 67 \mathrm{~Pa} / \mathrm{K})$. Now Eq.(37) becomes:

$$
a=\frac{4 \gamma M_{L} D_{v, f}}{\rho_{L} R} \cdot \frac{\Delta T}{T_{f}} \quad\left[\mathrm{~m}^{2} / \mathrm{s}\right]
$$

where $\Delta T=T-T_{w}$.

Since many parameters in Eqs.(38) and (42) are temperature dependent, so are parameters $a$ and $b$. At $15^{\circ} \mathrm{C}(\sim 298 \mathrm{~K})$ and $60 \%$ relative humidity, $a \approx 47.5 \cdot 10^{-12} \cdot \Delta T\left[\mathrm{~m}^{2} / \mathrm{s}\right]$ and $b \approx 62.0\left[\mathrm{~m}^{-1} \cdot \mathrm{s}^{0.5}\right]$. Variation in $b$ with temperature is only small. As long as $\Delta T$ remains constant, variation in $a$ is also small. At about $15^{\circ} \mathrm{C}$ the relative changes per degree turn out to be:

$$
\begin{aligned}
& \frac{1}{a} \frac{d a}{d T} \approx 0.004 \quad[1 / \mathrm{K}] \\
& \frac{1}{b} \frac{d b}{d T} \approx-0.003 \quad[1 / \mathrm{K}]
\end{aligned}
$$


This means that when ambient temperature rises from 10 to $20^{\circ} \mathrm{C}$, parameter $a$ increases by $4 \%$ and $b$ decreases by $3 \%$, provided that $\Delta T$ is constant. On the other hand, $a$ is proportional to $\Delta T$ and therefore sensitive to changes in $\Delta T$.

\subsubsection{Evaporation rate at sedimentation velocity}

Eq.(40) gives the evaporation rate of a water drop as a function of its diameter and velocity. According to Chapter 2 all drops released into air will eventually fall down at their sedimentation velocity, provided they have not impacted somewhere in the meantime. In the next section (3.3) it will be shown that with respect to evaporation the time between release and constant sedimentation often can be neglected, and an evaporating drop is at its sedimentation velocity most of the time during his flight. For such drops the evaporation rate can be calculated using the sedimentation velocities from Chapter 2 (Table 1, page 18). Table 4 shows computed values of the evaporation rate (from Eq.(40)) for high, medium and low humidity and at constant ambient temperature $\left(15^{\circ} \mathrm{C}\right)$, for drops falling through air at their sedimentation velocity. The values indicate that $K$ is approximately proportional to $\Delta T$, regardless of droplet diameter.

Figure 11 shows a graph of $K$ as a function of droplet diameter, using the values of Table 4. The linear regression lines indicate that $K$ increases almost linearly with increasing diameter. Apparently the non-linear equation (40) can be approximated by a linear equation. Since the factors $a$ and $b$ do not depend on drop diameter, the dependence on diameter must be implied solely by the square root of diameter and sedimentation velocity. Indeed it can be shown empirically that this square root is approximated by the following linear equation:

$$
\sqrt{D v_{s}} \approx r_{0} D+s_{0} \quad\left[\mathrm{~m} \cdot \mathrm{s}^{-0.5}\right]
$$

with $r_{0} \approx 64.65 \mathrm{~s}^{-0.5}$ and $s_{0} \approx-1.117 \cdot 10^{-3} \mathrm{~m} \cdot \mathrm{s}^{-0.5} \cdot\left(\mathrm{R}^{2}=0.999\right)$.

Rewriting Eq.(40) gives the following linear approximation:

$$
K=q_{0} \Delta T\left(1+q_{1} D\right) \quad\left[\mathrm{m}^{2} / \mathrm{s}\right]
$$

where

$$
\begin{aligned}
& q_{0}=\frac{2 a}{\Delta T}\left(1+b s_{0}\right) \quad\left[\mathrm{m}^{2} \cdot \mathrm{s}^{-1} \cdot \mathrm{K}^{-1}\right] \\
& q_{1}=\frac{b r_{0}}{1+b s_{0}} \quad\left[\mathrm{~m}^{-1}\right]
\end{aligned}
$$


Table 4. Evaporation rate of water drops at sedimentation velocity, at ambient temperature $15^{\circ} \mathrm{C}$ and wet-bulb temperatures 14,10 and $5{ }^{\circ} \mathrm{C}(\mathrm{RH} 90 \%, 52 \%$ and $12 \%$ respectively).

Tabel 4. Verdampingsconstante van waterdruppels bij sedimentatiesnelheid; omgevingstemperatuur $15^{\circ} \mathrm{C}$ en natte-bol temperatuur 14,10 en $5^{\circ} \mathrm{C}$ (resp. $\mathrm{RLV} 90 \%, 52 \%$ en $12 \%$ ).

\begin{tabular}{ccccc}
\hline $\begin{array}{c}D \\
{[\mu \mathrm{m}]}\end{array}$ & $\begin{array}{c}\left.v_{s}{ }^{2} / \mathrm{s}\right] \\
{[\mathrm{m}}\end{array}$ & $\begin{array}{c}K\left(\Delta T=1^{\circ} \mathrm{C}\right) \\
{\left[\mu \mathrm{m}^{2} / \mathrm{s}\right]}\end{array}$ & $\begin{array}{c}K\left(\Delta T=5^{\circ} \mathrm{C}\right) \\
{\left[\mu \mathrm{m}^{2} / \mathrm{s}\right]}\end{array}$ & $\begin{array}{c}K\left(\Delta T=10^{\circ} \mathrm{C}\right) \\
{\left[\mu \mathrm{m}^{2} / \mathrm{s}\right]}\end{array}$ \\
\hline 10 & 0.00300 & 97 & 479 & 944 \\
20 & 0.0118 & 99 & 488 & 963 \\
30 & 0.0260 & 101 & 499 & 986 \\
40 & 0.0452 & 104 & 513 & 1013 \\
50 & 0.0689 & 107 & 528 & 1043 \\
60 & 0.0965 & 110 & 544 & 1075 \\
70 & 0.128 & 113 & 561 & 1109 \\
80 & 0.162 & 117 & 579 & 1145 \\
90 & 0.198 & 121 & 598 & 1181 \\
100 & 0.237 & 124 & 617 & 1219 \\
150 & 0.455 & 144 & 716 & 1418 \\
200 & 0.692 & 165 & 819 & 1622 \\
250 & 0.935 & 186 & 923 & 1829 \\
300 & 1.18 & 207 & 1027 & 2035 \\
400 & 1.64 & 247 & 1226 & 2433 \\
500 & 2.07 & 286 & 1419 & 2816 \\
750 & 3.05 & 378 & 1879 & 3732 \\
1000 & 3.89 & 464 & 2307 & 4583 \\
\hline
\end{tabular}

${ }^{1}$ sedimentation velocities copied from Table 1, page 18.

Since $a$ and $b$ slightly depend on temperature, so do $q_{0}$ and $q_{1}$. Table 5 shows values of $q_{0}$ and $q_{1}$ at ambient temperatures 10,15 and $20^{\circ} \mathrm{C}$, for high, medium and low humidity (90, 50 and $20 \%$ respectively). While $q_{0}$ slightly increases with increasing temperature and humidity, for $q_{1}$ it is just the opposite. Thus these parameters tend to compensate each other with respect to their effect on $K$. Therefore, it can be expected that as long as $\Delta T$ remains constant the evaporation rate should not change much. Indeed Figure 12 shows that the evaporation rate hardly varies with ambient temperature, when $\Delta T$ is fixed at $5^{\circ} \mathrm{C}$. Note that $\mathrm{RH}$ is not constant in these cases and has medium-ranged values, yet this is not a prerequisite. 


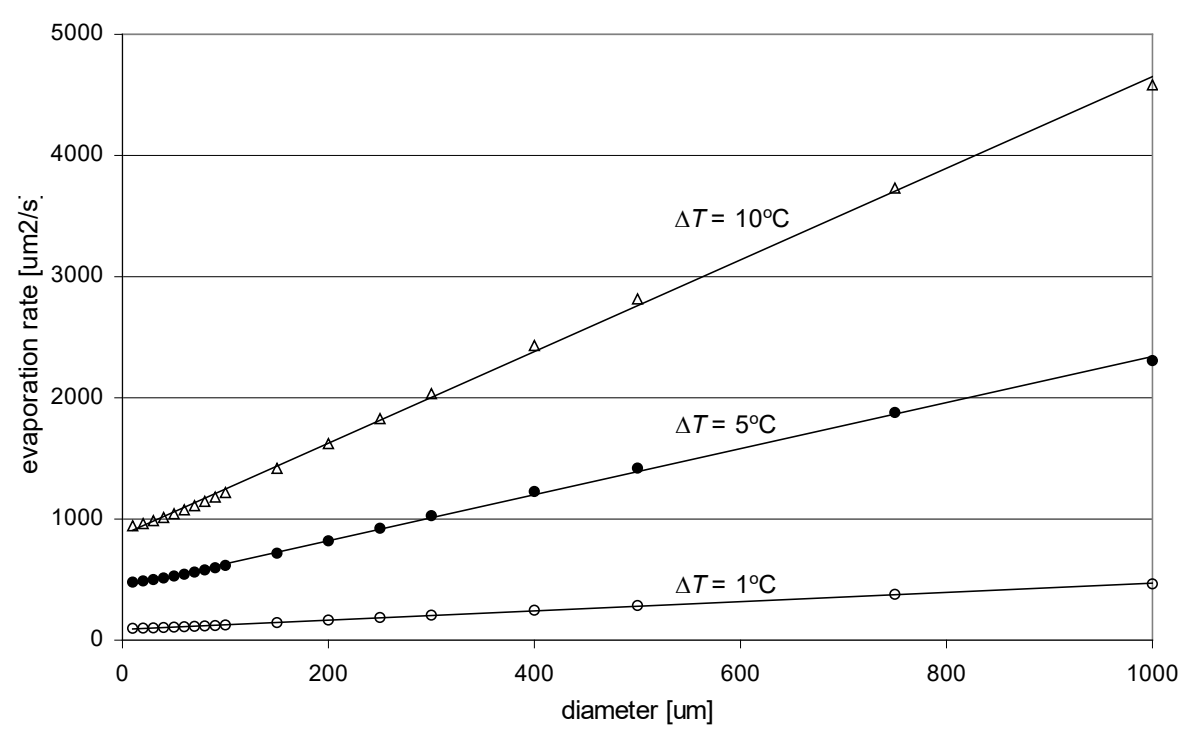

Figure 11. Evaporation rate $K$ for drops moving at sedimentation velocity through air. Ambient temperature $15^{\circ} \mathrm{C}$, wet-bulb temperatures 14,10 and $5^{\circ} \mathrm{C}(\mathrm{RH}$ respectively 90, 52 and 12\%). Dots: computed values (see Table 4); lines: linear regression.

Figuur 11. Verdampingsconstante $K$ voor druppels in lucht (bij sedimentatiesnelheid). Omgevingstemperatuur $15^{\circ} \mathrm{C}$, natte-bol temperatuur 14,10 and $5^{\circ} \mathrm{C}$ (resp. RLV 90, 52 en 12\%). Puntsymbolen: berekende waarden (zie Tabel 4); lijnen: lineaire regressie.

Table 5. Parameters $q_{0}$ and $q_{1}$ in linear approximation of evaporation rate for drops falling at sedimentation velocity, at three ambient temperatures and high, medium and low humidity.

Tabel 5. Parameters $q_{0}$ and $q_{1}$ in de lineaire benadering van de verdampingsconstante voor druppels bij sedimentatiesnelheid, bij drie omgevingstemperaturen en hoge, gemiddelde en lage luchtvochtigheid.

\begin{tabular}{ccccc}
\hline$T$ & $R H$ & $\Delta T$ & $q_{0}$ & $q 1$ \\
{$\left[{ }^{\circ} \mathrm{C}\right]$} & {$[\%]$} & {$\left[{ }^{\circ} \mathrm{C}\right]$} & {$\left[\mu \mathrm{m}^{2} \cdot \mathrm{s}^{-1} \cdot \mathrm{K}^{-1}\right]$} & $\begin{array}{c}\left.{ }^{1}\right] \\
{\left[\mu \mathrm{m}^{-1}\right]}\end{array}$ \\
\hline 10 & 90 & 0.8 & 87.18 & 0.00436 \\
& 50 & 4.4 & 86.29 & 0.00439 \\
& 20 & 7.4 & 85.56 & 0.00441 \\
15 & 90 & 1.0 & 89.14 & 0.00428 \\
& 50 & 5.2 & 88.07 & 0.00431 \\
& 20 & 8.9 & 87.16 & 0.00434 \\
20 & 90 & 1.1 & 91.10 & 0.00421 \\
& 50 & 6.1 & 89.84 & 0.00425 \\
& 20 & 10.6 & 88.74 & 0.00428 \\
\hline
\end{tabular}




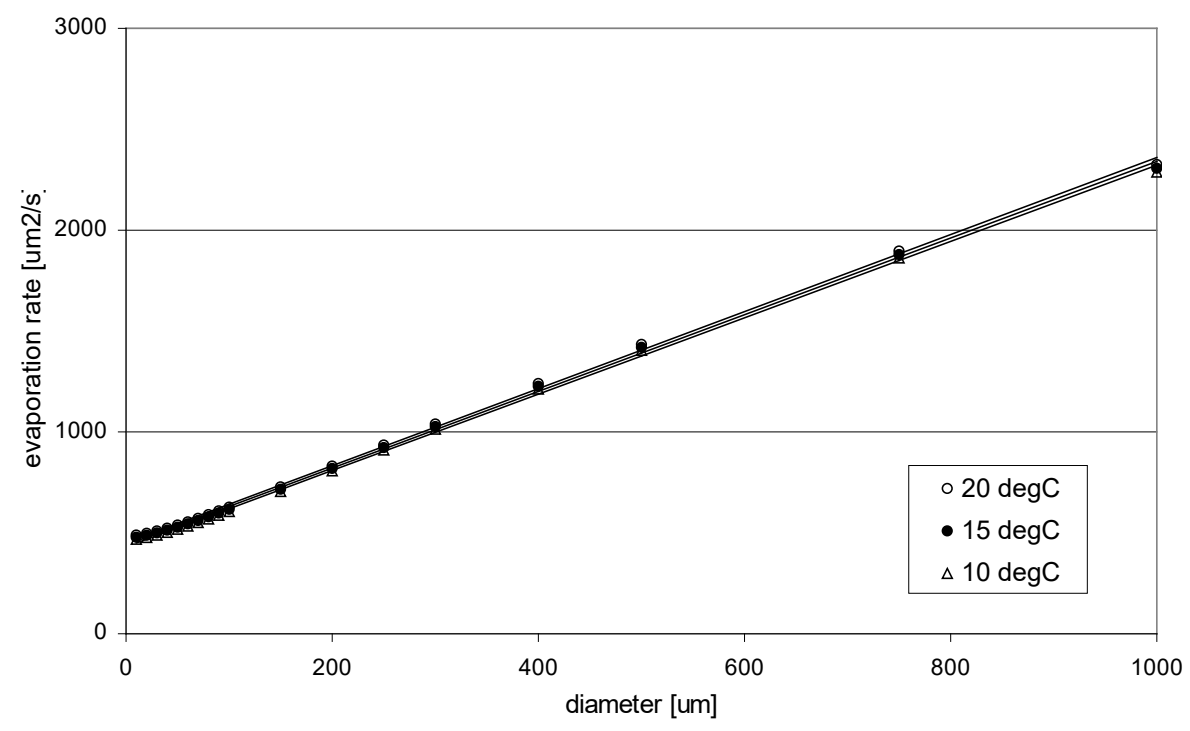

Figure 12. Evaporation rate $K$ for drops moving at sedimentation velocity through air. Ambient temperatures 10,15 and $20^{\circ} \mathrm{C}$, constant $\Delta T=5^{\circ} \mathrm{C}(\mathrm{RH} 44,52$ and 58\%, respectively). Dots: computed directly (Eq.(40)); lines: linear approximation (Eq.(46)).

Figuur 12. Verdampingsconstante $K$ voor druppels in lucht, bij sedimentatiesnelheid. Omgevingstemperaturen 10, 15 en $20^{\circ} \mathrm{C}$, en constant temperatuurverschil $\Delta T=5^{\circ} \mathrm{C}$ (resp. RLV 44, 52 en 58\%). Puntsymbolen: berekend uit Vgl.(40); lijnen: lineaire benadering $(V g l .(46))$.

\subsection{Lifetime of an evaporating water drop}

Usually drops produced by a hydraulic spray nozzle start at relatively high speed and slow down rapidly due to air friction (see Chapter 2). Soon they will arrive at a constant velocity, the sedimentation velocity. The rate of deceleration during the transient time is related to the relaxation time $\tau$. As this relaxation time is not constant, the distance-averaged relaxation time is a good choice for comparison with other characteristic time scales (Section 2.7).

With respect to evaporation two time scales have to be considered. Firstly, when a new drop is released in air, evaporation will start immediately. The drop will gradually cool down until it reaches its wet-bulb temperature (the value of which depends on ambient temperature and relative humidity). The first time scale is that of the transient time for cooling-down. Secondly, if the drop is at its stable wet-bulb temperature, it will continue to shrink due to 'steady' evaporation. Eventually, the drop vanishes when all water has evaporated. The second time scale is that related to 'steady' evaporation. The adjective 'steady' is merely used to distinguish the process from the initial cooling-down period; 
physically evaporation is not a 'steady' process, since the drop continuously shrinks and the evaporation rate changes correspondingly, as described in the previous section. In this section it will be assumed that the transient cooling-down period can be neglected with respect to total lifetime of a drop. Thus lifetime of a drop is completely determined by the process of steady evaporation. In Section 3.4 it will be shown that indeed the transient cooling-down period is much shorter than total lifetime.

Eqs.(39) and (46) describe the relation between droplet diameter and time. However, it is not easy to deduce an explicit expression for the diameter as a function of time.

Fortunately, the other way round, namely expressing time as a function of diameter, is relatively easy to carry out. In that case the differential equation to be solved is:

$$
\frac{d t}{d D}=\frac{-2 D}{q_{0} \Delta T\left(1+q_{1} D\right)} \quad[\mathrm{s} / \mathrm{m}]
$$

To eliminate the diameter from the numerator, the right-hand side can be rewritten as:

$$
\frac{d t}{d D}=\frac{-2}{q_{0} q_{1} \Delta T} \cdot\left(1-\frac{1}{1+q_{1} D}\right) \quad[\mathrm{s} / \mathrm{m}]
$$

Now integration is straightforward and yields:

$$
t(D)=\frac{-2 q_{1} D}{q_{0} q_{1}^{2} \Delta T}+\frac{2}{q_{0} q_{1}^{2} \Delta T} \ln \left(1+q_{1} D\right)+c \quad[\mathrm{~s}]
$$

where $c$ is an integration constant, which can be determined by considering that at $t=0$ the drop has its initial diameter $D_{0}$. On the other hand, the lifetime of the drop equals the time when the diameter has decreased to zero $(D=0)$. This results in the following expression for the lifetime of an evaporating drop:

$$
t_{\text {life }}=\frac{2}{q_{0} q_{1}^{2} \Delta T} \cdot\left[q_{1} D_{0}-\ln \left(1+q_{1} D_{0}\right)\right] \quad[\mathrm{s}]
$$

For small drops $\left(q_{1} D_{0}<<1\right.$; i.e. $\left.D_{0}<<230 \mu \mathrm{m}\right)$ the logarithm can be approximated by:

$$
\ln (1+x)=x-\frac{1}{2} x^{2}+O\left(x^{3}\right) \quad[-]
$$

In that case the lifetime of a small drop is approximately:

$$
t_{\text {life }}=\frac{D_{0}^{2}}{q_{0} \Delta T} \quad[\mathrm{~s}]
$$

This is similar to the relation given by Eq.(32) (Hartley and Graham-Bryce, 1980), though in that relation $q_{0}$ has a value significantly less than the values shown in Table 5. Besides, Eq.(54) is only valid for small drops which limits its applicability considerably. 


\subsection{Initial cooling-down period}

So far it has been assumed that a drop soon after its release will obtain the wet-bulb temperature and evaporation will be 'steady' from that time on. However, the size of the time interval for the initial cooling-down process is still unknown. In this section this time interval will be estimated and the results show that indeed this interval is very short with respect to total life time of a droplet.

Assume that a freshly released drop is at ambient temperature. Due to evaporation the drop will cool down, until it reaches the wet-bulb temperature (which depends on ambient temperature and relative humidity). In the final state of 'steady' evaporation the drop temperature is stable, because the energy required to evaporate liquid is compensated exactly by the heat flowing from ambient air towards the cold drop. A similar energy balance is valid during the cooling-down period, though in that period the heat flux from ambient air is lower than evaporation needs, leading to withdrawal of thermal energy from the drop itself. Or in an equation:

$$
P_{\text {evap }}=P_{\text {ambient }}+P_{\text {cooling }} \quad[\mathrm{W}]
$$

The required power (i.e. energy per unit time) to evaporate a volume $d V$ during a small time interval $d t$ is equal to:

$$
P_{\text {evap }}=-b \rho_{L} \frac{d V}{d t}=-\frac{1}{2} \pi h \rho_{L} D^{2} \frac{d D}{d t} \quad[\mathrm{~W}]
$$

where $h$ is the evaporation heat (water: $h=22.6 \times 10^{5} \mathrm{~J} / \mathrm{kg}$; i.e. the amount of energy to transfer $1 \mathrm{~kg}$ of liquid into vapour). If during that interval the drop temperature changes by $d T(<0)$, the power withdrawn (leading to cooling) is:

$$
P_{\text {cooling }}=-c_{p} \rho_{L} V \frac{d T}{d t}=-\frac{1}{6} \pi c_{p} \rho_{L} D^{3} \frac{d T}{d t} \quad[\mathrm{~W}]
$$

where $c_{p}$ is the specific heat (water: $c_{p}=4180 \mathrm{~J} \cdot \mathrm{kg}^{-1} \cdot \mathrm{K}^{-1}$.; i.e. the amount of energy required to heat up $1 \mathrm{~kg}$ of material by $1 \mathrm{~K}$ ).

The heat withdrawn from ambient air (temperature $T_{d}$ ) by a drop at temperature $T^{\prime}$ 'can be expressed as:

$$
P_{\text {ambient }}=\alpha\left(T_{d}-T^{\prime}\right) \quad[\mathrm{W}]
$$

where $\alpha$ is a heat transfer coefficient that still needs to be determined. It is common practice to assume that $\alpha$ does not depend on temperature, yet it depends on drop size and velocity. This means that the heat transfer coefficient does not change during cooling (as far as drop size does not change too much). Consequently, $\alpha$ can be obtained from steady evaporation: 


$$
P_{\text {evap, steady }}=P_{\text {ambient }} \quad[\mathrm{W}]
$$

which gives:

$$
\alpha=\frac{-\pi h \rho_{L} D^{2}}{2\left(T_{d}-T_{w}\right)} \cdot \frac{d D}{d t} \quad[\mathrm{~W} / \mathrm{K}]
$$

Here $d D / d t$ is related to steady evaporation: the temperature of the drop is $T_{w}$ (though its velocity may differ from sedimentation velocity).

Now Eqs.(55), (56), (57), (58) and (60) can be combined, and after rearranging, the rate of change of drop temperature results:

$$
\frac{d T}{d t}=\frac{3 h}{c_{p} D}\left\{\frac{d D}{d t}(t r)-\frac{T_{d}-T^{\prime}}{T_{d}-T_{w}} \cdot \frac{d D}{d t}(s t)\right\} \quad[\mathrm{K} / \mathrm{s}]
$$

where the suffixes (tr) and (st) refer to transient (i.e. cooling-down period) and steady evaporation. The rates of decrease of drop size in transient and steady situation are both described by Eq.(36), and differ only in the saturated vapour pressure near the drop surface. For the initial cooling-down period:

$$
\frac{d D}{d t}(t r)_{D}=\frac{-\zeta}{D}(1+b \sqrt{D v})\left(p_{s a t, T^{\prime}}-p\right) \quad[\mathrm{m} / \mathrm{s}]
$$

And for the steady situation:

$$
\frac{d D}{d t}(s t)=\frac{-\zeta}{D}(1+b \sqrt{D v})\left(p_{s a t, T w}-p\right) \quad[\mathrm{m} / \mathrm{s}]
$$

with

$$
\zeta=\frac{4 M_{L} D_{v, f}}{\rho_{L} R T_{f}} \quad\left[\mathrm{~m}^{2} \cdot \mathrm{s}^{-1} \cdot \mathrm{Pa}^{-1}\right]
$$

Note that in the first case the saturated vapour pressure is needed at a decreasing temperature $T$, , while in the second case this pressure is needed at the wet-bulb temperature $T_{w}$.

$$
\frac{d T}{d t}=\frac{3 b \zeta}{c_{p} D^{2}}(1+b \sqrt{D v})\left\{-p_{s a t, T^{\prime}}+p+\frac{T_{d}-T^{\prime}}{T_{d}-T_{w}} \cdot\left(p_{s a t, T w}-p\right)\right\}
$$

If dry-bulb and wet-bulb temperatures do not differ too much, saturated vapour pressure can be approximated by a linear equation:

$$
p_{s a t, T^{\prime}}=p_{s a t, T w}+\frac{d p_{s a t}}{d T} \cdot\left(T^{\prime}-T_{w}\right) \quad[\mathrm{Pa}]
$$


Though the derivative of pressure should be calculated at temperature $T_{w}$, it is often more convenient to calculate it at the average temperature between dry-bulb and wet-bulb temperature $\left(T_{f}\right)$ to compensate for non-linearity in pressure between $T_{w}$ and $T_{d}$. The derivative of saturated vapour pressure can be obtained from Eq.(C.1) (Appendix C):

$$
\frac{d p_{\text {sat }}}{d T}=\frac{b_{0} b_{1} \ln 10}{\left(T+b_{1}\right)^{2}} \cdot p_{\text {sat }} \quad[\mathrm{Pa} / \mathrm{K}]
$$

with constants $b_{0}=7.5$ and $b_{1}=237.3$. At $15^{\circ} \mathrm{C}$ the approximate value of this derivative is $110 \mathrm{~Pa} / \mathrm{K}$.

Finally, using Eq.(41), the rate of change of temperature is given by:

$$
\frac{d T}{d t}=-\frac{3 b \zeta}{c_{p} D^{2}}(1+b \sqrt{D v})\left(\frac{d p_{s a t}}{d T}+\gamma\right)\left(T^{\prime}-T_{w}\right) \quad[\mathrm{K} / \mathrm{s}]
$$

Provided that $D$ and $v$ do not change much during the cooling-down period, the solution of this differential equation is simply an exponential decay of temperature:

$$
T^{\prime}=T_{w}+\left(T_{d}-T_{w}\right) e^{-t / \tau_{c}} \quad[\mathrm{~K}]
$$

with characteristic time scale:

$$
\tau_{c}=\frac{c_{p} D^{2}}{3 b \zeta(1+b \sqrt{D v})\left(\frac{d p_{s a t}}{d T}+\gamma\right)} \quad[\mathrm{s}]
$$

At release, the velocity of a drop is (much) higher than its sedimentation velocity. In this high-velocity air stream flowing around the drop, vapour is more easily transported away from the drop, and heat is more easily transported towards the drop. Indeed the rate of evaporation increases with increasing velocity (e.g. see Eq.(62)) but also the heat transfer coefficient is enhanced (Eq.(60)). As a result the time scale $\tau_{c}$ is lower for high-speed drops than for low-speed drops.

In Table 6 several time scales are compared: the time scale for deceleration $\left(\tau_{s}\right)$, for cooling-down $\left(\tau_{c}\right)$ and for evaporation (i.e. total lifetime $t_{\text {life }}$ ). The first two time scales correspond to transient processes. If these time scales are much shorter than lifetime, 'steady' evaporation gives a good description of actual evaporation. If the transient processes occur on a time scale similar to lifetime, or even slower, their effect on evaporation cannot be neglected, which makes a satisfactory description of evaporation more elaborate. It turns out that the ratios $t_{\text {iffe }} / \tau_{s}$ and $t_{\text {iffe }} / \tau_{c}$ are very large $(>800$ and $>500$ respectively; Table 6) at ambient temperature $15^{\circ} \mathrm{C}$ and $60 \%$ relative humidity. Even when considering a 'worst case' of $30^{\circ} \mathrm{C}$ and $20 \%$ humidity (warm and dry) with fast evaporation 
Table 6. Comparison of transient time scales and lifetime for evaporating water drops in air; ambient temperature $15^{\circ} \mathrm{C}, \mathrm{RH} 60 \%{ }^{(1)}$.

Tabel 6. Vergelijking van tijdschalen van overgangsprocessen en levensduur voor verdampende waterdruppels in lucht; omgevingstemperatuur $15^{\circ} \mathrm{C}, \mathrm{RLV} 60 \%{ }^{(1)}$.

\begin{tabular}{ccccccc}
\hline $\begin{array}{c}D \\
{[\mu \mathrm{m}]}\end{array}$ & $\begin{array}{c}\tau_{s}(2) \\
{[\mathrm{s}]}\end{array}$ & $\begin{array}{c}\tau_{c}(3) \\
{[\mathrm{s}]}\end{array}$ & $\begin{array}{c}t_{\text {life }}(4) \\
{[\mathrm{s}]}\end{array}$ & $\begin{array}{c}t_{\text {life }} / \tau_{s} \\
{[-]}\end{array}$ & $\begin{array}{c}t_{\text {life }} / \tau_{c} \\
{[-]}\end{array}$ & $\begin{array}{c}K_{\text {avg }}(5) \\
{\left[\mu \mathrm{m}^{2} / \mathrm{s}\right]}\end{array}$ \\
\hline 10 & 0.00031 & 0.00053 & 0.27 & 873 & 507 & 374 \\
20 & 0.00120 & 0.0021 & 1.04 & 863 & 503 & 385 \\
30 & 0.00265 & 0.0045 & 2.28 & 858 & 502 & 395 \\
40 & 0.00461 & 0.0079 & 3.95 & 856 & 503 & 405 \\
50 & 0.00702 & 0.0119 & 6.02 & 857 & 505 & 415 \\
75 & 0.0147 & 0.0249 & 12.8 & 869 & 514 & 441 \\
100 & 0.0242 & 0.0409 & 21.5 & 889 & 526 & 465 \\
150 & 0.0463 & 0.0792 & 43.7 & 944 & 553 & 514 \\
200 & 0.0705 & 0.1231 & 71.1 & 1008 & 578 & 562 \\
300 & 0.120 & 0.221 & 137 & 1144 & 620 & 657 \\
500 & 0.211 & 0.444 & 298 & 1408 & 670 & 840 \\
\hline
\end{tabular}

(1) $T_{w}=10.9^{\circ} \mathrm{C} ; \rho_{L}=999.5 \mathrm{~kg} / \mathrm{m}^{3}, \rho_{a}=1.230 \mathrm{~kg} / \mathrm{m}^{3}, \eta_{a}=17.9 \mu \mathrm{Pa} . \mathrm{s}, D_{v}=23.1 \mu \mathrm{m}^{2} / \mathrm{s}$.

(2) taken from Table 1, page 18.

(3) calculated from $\mathrm{Eq} .(70)$, with $v=v$ s. (from Table 1, page 18).

(4) calculated from Eq.(52).

(5) time averaged evaporation rate: $D^{2} / t_{\text {tife }}$

and therefore short lifetimes, it can be shown that both ratios are well over 200 for all relevant drop sizes $(10-1000 \mu \mathrm{m})$. Apparently in practical cases transient effects can be neglected when considering total evaporation of a drop.

In Section 2.7 it was shown that adaptation time for droplet velocity is roughly twice the relaxation time $\left(\boldsymbol{\tau}_{s}\right)$. Now Table 6 shows that this adaptation time appears to be in the same order of magnitude as the time required for cooling-down $\left(\boldsymbol{\tau}_{c}\right)$. This means that the exponential temperature decay (Eq.(69)) does not describe temperature change very well, since it assumes velocity to be constant. Indeed, Figure 13 shows that the actual temperature decrease of a decelerating droplet differs from that at constant velocity. Both series of dots appear to follow an exponential decay very well. The actual temperature decrease initially follows the lower dotted curve, but soon the drop slows down and temperature decrease gets slower and decays with a characteristic time corresponding to the upper dotted curve. It can be shown that velocity adaptation occurs slightly faster than temperature adaptation; this corresponds to $\tau_{s}$ being less than $\tau_{c}$. 


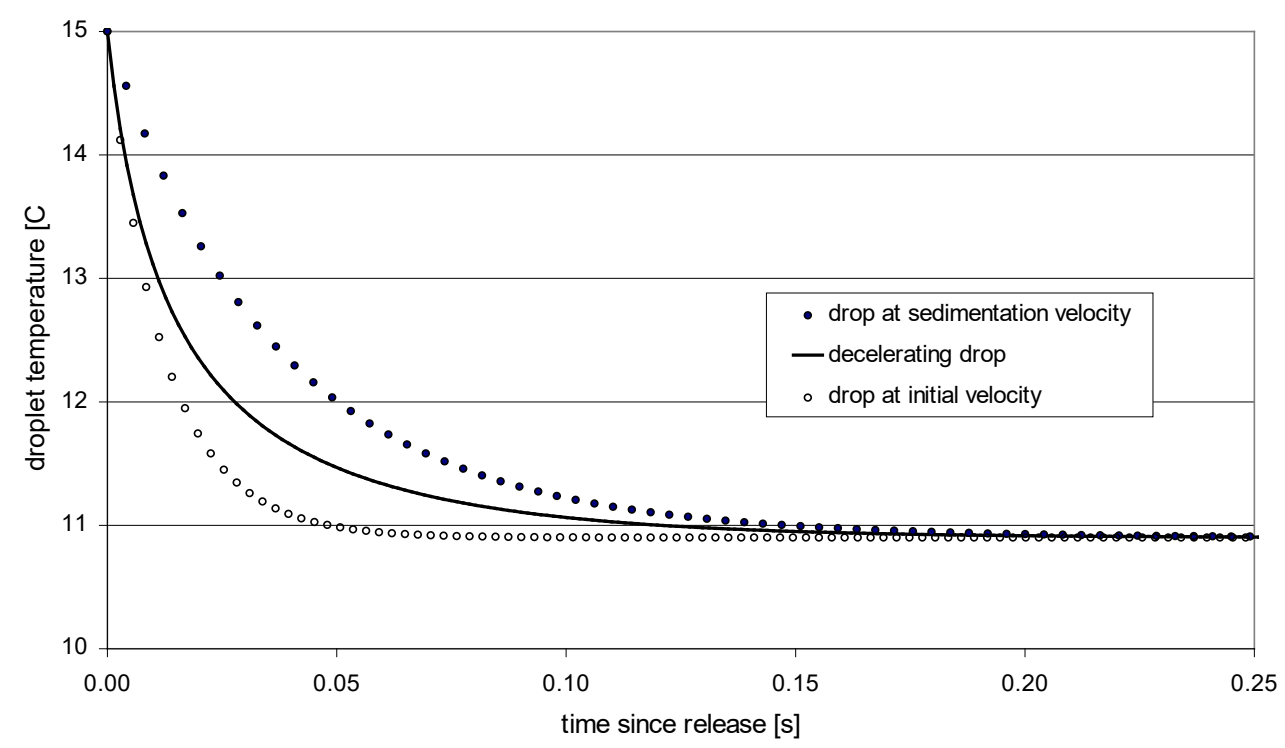

Figure 13. Temperature of a water drop in air, as a function of time after release. Initial diameter $100 \mu \mathrm{m} ; T_{d}=15^{\circ} \mathrm{C} ; T_{w}=10.9^{\circ} \mathrm{C}(R H=60 \%)$; initial velocity $20 \mathrm{~m} / \mathrm{s}$ downward. The closed dots represent the temperature for a drop at its sedimentation velocity all the time; similarly, the open dots represent a drop remaining at its initial velocity.

Figuur 13. Temperatuur van een waterdruppel in lucht als functie van de tijd sinds zijn ontstaan. Begindiameter $100 \mu \mathrm{m} ; \mathrm{T}_{d}=15^{\circ} \mathrm{C} ; \mathrm{T}_{w}=10.9^{\circ} \mathrm{C}(\mathrm{RLV}=60 \%)$; beginsnelheid $20 \mathrm{~m} / \mathrm{s}$ neerwaarts. De dichte stippen verwijzen naar het temperatuursverloop als de druppel steeds zijn sedimentatiesnelheid had. De open stippen verwijzen naar het verloop voor een druppel die zijn beginsnelheid behoudt.

\subsection{Validation}

In experiments of Williamson and Threadgill (1974) small packages ('clouds') of uniform drops were released in a wind tunnel. Averaged velocity and size of the drops were measured near the point of release. At various distances downwind averaged drop size was measured, and horizontal and vertical position relative to the point of release were recorded. The experiments included several wind velocities; a natural wind profile was simulated using a mesh wire placed upwind, to introduce flow resistance near the floor of the wind tunnel. Dry-bulb and wet-bulb temperature were measured as well.

In our study, these experiments were simulated with the IDEFICS spray drift model (version 3.1), using settings corresponding to the experiments described above. In IDEFICS, droplet trajectory calculation is based on the theory given in chapter 2, while calculation of evaporation is based on the current chapter. In the simulations, drops were 
released vertically at the given velocity, and at a height $2 \mathrm{~m}$ above bare ground. A logarithmic wind profile was assumed, without turbulence. The droplet trajectory was recorded and compared to the averaged positions from the experiments mentioned above. Initial velocity was adjusted by changing liquid pressure. For each series of experiments (determined by drop size and wind speed), one simulation was done. Input parameters like drop size, initial velocity, and temperatures were averaged for each series. Table 7 shows the essential parameters for the simulations.

If the decrease of drop size is relatively small, according to Eq.(46) the evaporation rate does not change much. In that case this equation can be rewritten into:

$$
D^{2}=D_{0}^{2}-K t=D_{0}^{2}-q_{0}\left(1+q_{1} D\right) \Delta T t \quad[\mathrm{~s}]
$$

where $D_{0}$ is the initial diameter and $t$ is the time elapsed since release. Now along a droplet trajectory $q_{0}, q_{1}$ are almost constant, and $D \approx D_{0}$ in the experiments, so $D^{2}$ changes almost linearly with 'humidity-scaled time' $\Delta T \cdot t$. Figure 14 shows the diameter squared as a function of humidity-scaled time. Experiments (open and closed dots) as well as simulations (lines) show a linear decrease of diameter squared with time. Obviously the relative decrease of diameter is less for drops with diameter of about $220 \mu \mathrm{m}$ than for those of $110 \mu \mathrm{m}$. Results from the simulations agree with the experimental results.

Table 7. Settings for IDEFICS simulations of wind tunnel experiments according to Williamson and Threadgill (1974). All parameters are averaged over the test numbers indicated.

Tabel 7. Instellingen voor IDEFICS-simulaties van experimenten in een windtunnel (Williamson en Threadgill, 1974). Alle parameters zijn gemiddeld over de aangegeven deelexperimenten.

\begin{tabular}{ccccccc}
\hline Test no. ${ }^{(1)}$ & $\begin{array}{c}\text { Wind speed } \\
\text { (at 2 m) } \\
{[\mathrm{m} / \mathrm{s}]}\end{array}$ & $\begin{array}{c}T_{d y} \\
{\left[{ }^{\circ} \mathrm{C}\right]}\end{array}$ & $\begin{array}{c}T_{\text {wet }} \\
{\left[{ }^{\circ} \mathrm{C}\right]}\end{array}$ & $\begin{array}{c}R H \\
{[\%]}\end{array}$ & $\begin{array}{c}D_{0} \\
{[\mu \mathrm{m}]}\end{array}$ & $\begin{array}{c}\nu_{0} \\
{[\mathrm{~m} / \mathrm{s}]}\end{array}{ }^{(3)}$ \\
\hline $1-1-1 / 5$ & 2.9 & 27.1 & 19.4 & 49 & 226 & 0.92 \\
$1-2-1 / 5$ & 2.2 & 28.8 & 19.8 & 43 & 210 & 0.92 \\
$1-3-1 / 3$ & 1.2 & 28.9 & 23.7 & 65 & 218 & 0.88 \\
$1-4-1 / 2$ & 0.9 & 26.1 & 23.5 & 81 & 214 & 0.88 \\
$2-4-1 / 5$ & 2.9 & 32.1 & 24.1 & 52 & 111 & 0.47 \\
$2-2-1 / 7$ & 2.2 & 27.7 & 24.0 & 74 & 114 & 0.44 \\
$2-3-1 / 7$ & 1.2 & 29.5 & 23.9 & 63 & 113 & 0.40 \\
$2-1-2 / 7$ & 0.9 & 25.2 & 22.7 & 81 & 112 & 0.38 \\
\hline
\end{tabular}

(1) numbering of experiments according to Williamson and Threadgill (1974)

(2) relative bumidity calculated from dry-bulb and wet-bulb temperature

(3) initial velocity adjusted by changing liquid pressure accordingly 


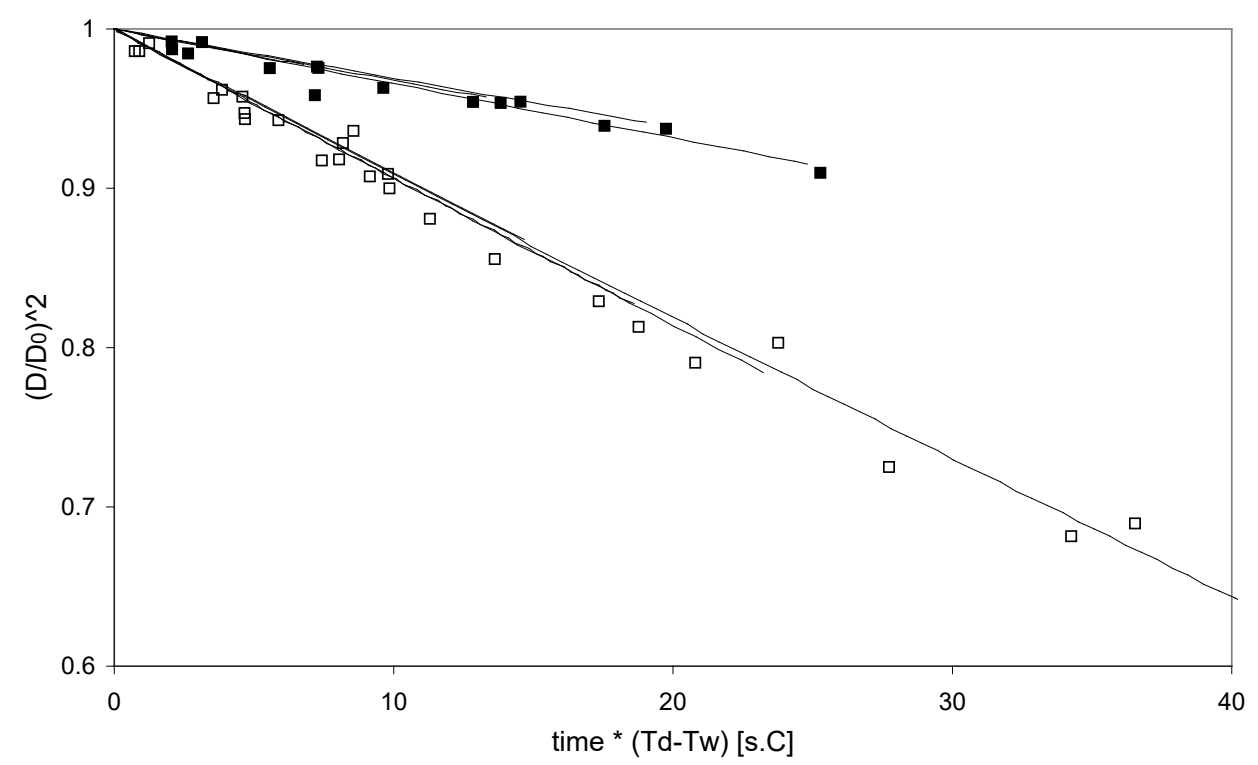

Figure 14. Comparison of evaporation experiments of Williamson and Threadgill (1974) (open and closed dots) and simulations using IDEFICS (lines). The vertical axis gives relative drop diameter squared; the horizontal axis is humidity-corrected time. Closed squares and upper lines represent drops with diameter of about $220 \mu \mathrm{m}$; open squares and lower lines those of about $110 \mu \mathrm{m}$.

Figuur 14. Vergelijking van de verdampingsexperimenten van Williamson en Threadgill (1974) (open and dichte symbolen) met IDEFICS-simulaties (lijnen).De verticale as representeert het kwadraat van de relatieve druppeldiameter; de horizontale as de tijd met 'vochtigheidscorrectie'. Gesloten symbolen en bovenste lijnen: druppels met diameter van ca. $220 \mu \mathrm{m} ;$ open symbolen en onderste lijnen: druppels van ca. $110 \mu \mathrm{m}$.

\subsection{Discussion}

In this chapter the evaporation of spherical water drops in air was described. The general equation (Eq.(33)) could be simplified considerably, provided that transient processes could be neglected. Transient processes (velocity and temperature adaptation) were shown to occur on a time scale much shorter than total lifetime of a water drop. Therefore evaporation of a droplet can be approximated closely by steady evaporation. Evaporation rate $K$ is approximated well by a linear function of drop diameter and the difference between dry-bulb and wet-bulb temperature. Comparison of the present evaporation model with wind tunnel experiments showed a close agreement. Besides, both experiments 
and model calculations showed a linear decrease of drop diameter squared with time, indicating that transient processes did not affect overall evaporation significantly.

In several cases, however, transient processes cannot be neglected. These include simulation of relatively large drops in drift studies. In these cases the time of flight of drops is much shorter than their lifetime, because the drops will impact on the ground quickly. The time of flight for such drops released at high speed may be in the same order of magnitude as the time scale of the transient processes. Although the evaporation rate for large drops is higher than that for small drops (see Eq.(46)), the time of flight is so short that no significant evaporation will occur. This means that, whether transient processes are calculated accurately, or just the steady evaporation model is used, in both cases the volume of evaporated liquid for large drops is negligible with respect to evaporation of relatively small drops.

Intuitively, small drops evaporate more rapidly than large drops. This is supported by lifetime increasing progressively for increasing drop size. This seems in contrast with Eq.(46), showing that evaporation rate increases with increasing diameter. Evaporation rate, however, is based on the change in diameter squared (i.e. the change in evaporative surface), while 'visual' evaporation is related to change in diameter itself. E.g. halving the drop diameter by evaporation takes much more energy and consequently much more time for a large drop than for a small drop, supporting the intuitively rapid evaporation of small drops. However, the liquid volume changed into vapour is much larger for the large drop than for the small drop. So a large evaporating drop produces vapour more quickly than a small drop, yet the corresponding change in diameter is less pronounced for the larger drop.

For drops from aqueous suspensions evaporation often takes place as if the drop was pure water, until the moment that all water has evaporated and only the suspended material remains (Elliott and Wilson, 1983). This 'solid core' approach (as if all suspended solids are centred in the core) has the advantage of using the model above for all kinds of suspensions and solutions. However, it may affect lifetime, since evaporation of water stops at a non-zero diameter. Yet for drops with high water content ( $>90 \%$ by volume) this effect on lifetime is often negligible.

Effort has been made to develop spray formulations that may slow down evaporation. Often such formulations merely affect drop size spectrum (effectively by increasing drop sizes). Indirectly this indeed affects evaporation, but it also has considerable consequences for the distribution of deposition and drift of spray drops, regardless of evaporation. Therefore, as long as the 'solid core' approach is valid, the given theory of evaporation can be applied. 
The presented model can be used for other solvents as well, provided that parameters like molecular weight, diffusion coefficient and saturated vapour pressure are known.

Obviously in such cases the vapour pressure in ambient air often is zero. Additionally, quantities like dry-bulb and wet-bulb temperature have no meaning for solvents other than water, and pressure difference cannot be converted into a temperature difference. This, however, is no limitation for using the model in a slightly adapted form. 


\section{References}

Eck, B., 1961

Technische Strömungslehre.

Springer Verlag; Berlin; 453 pp.; Sections 54, 78.

Elliott, J.G., and Wilson, B.J., (eds.), 1983

The influence of weather on the efficiency and safety of pesticide application. The drift of pesticides.

Occasional Publication No.3, British Crop Protection Council (BCPC); croydon UK; 135 pp.

Gates, D.M., 1980

Biophysical ecology.

Springer Verlag; New York, Heidelberg, Berlin; 611 pp.

Goering, C.E., Bode, L.E., Gebhardt, M.R., 1972

Mathematical modeling of spray droplet deceleration and evaporation.

Transactions of the ASAE 15: 220-225.

Holterman, H.J., J.C. van de Zande, H.A.J. Porskamp, J.F.M. Huijsmans, 1997

Modelling spray drift from boom sprayers.

Computers and Electronics in Agriculture, 19: 1-22.

Lefebvre, A.H., 1989

Atomization and sprays.

Hemisphere Publishing Corporation; New York, Washington, Philadelphia, London; 421 pp.

List, R.J., (Ed.) 1958

Smithsonian Meteorological Tables.

$6^{\text {th }}$ revised ed., $1^{\text {st }}$ reprint; Smithsonian Miscellaneous Collections, Vol 114;

Smithsonian Institution; City of Washington, USA.

May, K.R., R. Clifford, 1967

The impaction of aerosol particles on cylinders, spheres, ribbons and discs. Annals of Occupational Hygiene, 10: 83-95. 
Monteith, J.L., Unsworth, M.H., 1990

Principles of environmental physics.

Edward Arnold; London, etc.; 290 pp.

Ranz, W.E., Marshall, W.R., 1952a

Evaporation from drops; Part I.

Chemical Engineering Progress 48(3): 141-146.

Ranz, W.E., Marshall, W.R., 1952b

Evaporation from drops; Part II.

Chemical Engineering Progress 48(4): 173-180.

Tomlin, C.D.S. (Ed.), 1997

Pesticide Manual.

$11^{\text {th }}$ edition, British Crop Protection Council (BCPC), Farnham, Surrey, UK.

Weast, R.C. (Ed.), 1986

CRC Handbook of Chemistry and Physics.

$67^{\text {th }}$ edition, CRC Press Inc., Boca Raton, Florida, USA.

Williamson, R.E., Threadgill, E.D., 1974

A simulation for the dynamics of evaporating spray droplets in agricultural spraying.

Transactions of the ASAE 17: 254-261. 


\section{Summary}

This report deals with two important topics on the theory of in-flight water drops: kinetics and evaporation. In chapter 2 the flow of a spherical drop through air is described. The drop experiences forces like gravity and air resistance, which determine its path through air. Initial velocity, drop size and wind velocity are important factors. Air flow around a drop can be laminar or turbulent; in practice only for small drops ( $<50 \mu \mathrm{m}$ diameter) flow is laminar. Aspects like sedimentation velocity, stopping distance and relaxation time are discussed. At first these aspects seem rather theoretical, yet they gain in practical importance when considering impaction of drops onto objects that obstruct the flow path of the drops. An empirical relation for the estimation of the efficiency for water drops impacting onto a spherical target is derived. This relation can be used to calculate airborne spray drift by correcting the measured drift based on the calculated efficiency. The kinetic model as presented in chapter 2 has a direct application in the spray drift model IDEFICS.

Chapter 3 deals with evaporation of aqueous drops in air. Important parameters are ambient air temperature and relative humidity, as well as aspects related to the drop itself: its size and relative velocity. It is shown that transient processes like velocity adaptation and cooling-down affect evaporation, yet in practice the time scales involved are much shorter than total lifetime of an evaporating drop. This implies that in practical cases transient processes can be neglected and the subsequent 'steady' evaporation gives a good estimation of overall evaporation. Steady evaporation is described simply by the evaporation rate, which, in contrast to some references in literature, not only depends on temperature and humidity, but also on droplet size. In a good approximation, evaporation rate is proportional to the difference in dry-bulb and wet-bulb temperature, and increases linearly with increasing droplet diameter. For relatively small drops, lifetime is proportional to diameter squared, and inversely proportional to the difference in dry-bulb and wet-bulb temperature. The presented evaporation model is used in the spray drift model IDEFICS. Comparison of simulations and wind tunnel experiments from literature shows a good agreement.

The presented theory is not limited to implementation in the IDEFICS model, but can be used typically in almost all models describing in-flight water drops. With relatively simple modifications an extension to drops of other liquids is possible. 


\section{Samenvatting}

In dit rapport worden twee belangrijke theoretische aspecten van druppels in lucht behandeld: beweging en verdamping. In hoofdstuk 2 wordt de beweging van een ronde druppel in lucht beschreven. De druppel ondervindt zwaartekracht en luchtweerstand, die de druppelbaan door de lucht bepalen. De beginsnelheid en grootte van de druppel, en de windsnelheid zijn belangrijke factoren. De luchtstroming rondom een druppel kan laminair of turbulent zijn; in praktijk is alleen voor kleine druppels $(<50 \mu \mathrm{m}$ in diameter) de stroming laminair. Verder wordt aandacht besteed aan aspecten als sedimentatiesnelheid, 'stopping distance' (stopafstand) en relaxatietijd. Op het eerste gezicht lijken deze aspecten nogal theoretisch, maar hun belang wordt duidelijk bij de botsing van druppels met objecten die de druppelbanen versperren. Een empirische verband is afgeleid voor de schatting van de botsingsefficiëntie van waterdruppels op bolvormige objecten. Met dit verband kan druppeldrift naar de lucht berekend worden door gemeten drift te corrigeren op basis van een berekende botsingsefficiëntie. Het kinetische model uit hoofdstuk 2 wordt rechtstreeks toegepast in het driftmodel IDEFICS.

In hoofdstuk 3 wordt de verdamping van waterdruppels behandeld. Belangrijke parameters zijn omgevingstemperatuur en relatieve luchtvochtigheid, maar ook aspecten die op de druppel zelf betrekking hebben: zijn grootte en relatieve snelheid. Overgangsprocessen zoals snelheidsaanpassing en afkoeling van de druppel blijken de verdamping te beïnvloeden. In praktijk blijken de karakteristieke tijdschalen voor deze overgangsprocessen veel korter te zijn dan de totale levensduur van een verdampende druppel. Deze processen kunnen daarom verwaarloosd worden, en met de daaropvolgende stationaire verdamping kan het totale verdampingsproces goed beschreven worden. Stationaire verdamping wordt beschreven aan de hand van een verdampingsconstante, die niet alleen van temperatuur en luchtvochtigheid afhangt (zoals soms in de literatuur wordt beweerd) maar ook van de druppelgrootte. In goede benadering is de verdampingsconstante evenredig met het verschil tussen droge- en natte-bol temperatuur, en neemt lineair toe met de druppeldiameter. De levensduur van betrekkelijk kleine druppels is evenredig met het kwadraat van hun diameter, en omgekeerd evenredig met het verschil tussen droge- en natte-bol temperatuur. Het besproken verdampingsmodel wordt toegepast in het driftmodel IDEFICS. Een vergelijking van simulaties en experimenten in een windtunnel (literatuur) tonen een goede overeenstemming.

Het besproken model blijft niet beperkt tot gebruik in het model IDEFICS, maar kan in vrijwel alle modellen voor vrije waterdruppels in lucht toegepast worden. Bovendien kan het model op betrekkelijk eenvoudige wijze aangepast worden voor druppels van andere vloeistoffen. 


\section{Appendix A. Molecular view of evaporation}

Above zero absolute temperature every molecule has a certain kinetic energy, the amount of which is directly related to temperature. For instance molecules in a liquid roll over each other constantly. However, the kinetic energy of molecules in a liquid is not the same for all molecules. Molecules in the liquid roughly remain together because they are bound to their neighbours by intermolecular forces. At the interface between liquid and air, for instance, liquid molecules have less neighbours than inside the liquid. Therefore they are bound to their neighbours not as strong as inside the liquid. Especially molecules with relatively high kinetic energy can escape relatively easily from the liquid into the air above. In the macroscopic world, this process of escaping molecules is called 'evaporation'.

Molecules in the vapour phase move at relatively high velocity, and collide every now and then with each other (and with air molecules if present). They also collide with the walls, if the liquid and vapour is contained in a closed vessel (see Figure A.1). Macroscopically, the infinite stream of molecules hitting the walls is actually equivalent to the phenomenon of pressure. In the case of vapour molecules, it is called vapour pressure.

Vapour molecules may also return into the liquid. In a closed vessel at constant temperature, eventually the flux of returning molecules compensates the flux of evaporating molecules. At this equilibrium, the space above the liquid is at its highest vapour concentration; the corresponding pressure is called 'saturated vapour pressure'. Since kinetic energy of gaseous molecules appears to be proportional to temperature, a rise in temperature implies a rise in flux of escaping molecules, and consequently an equilibrium

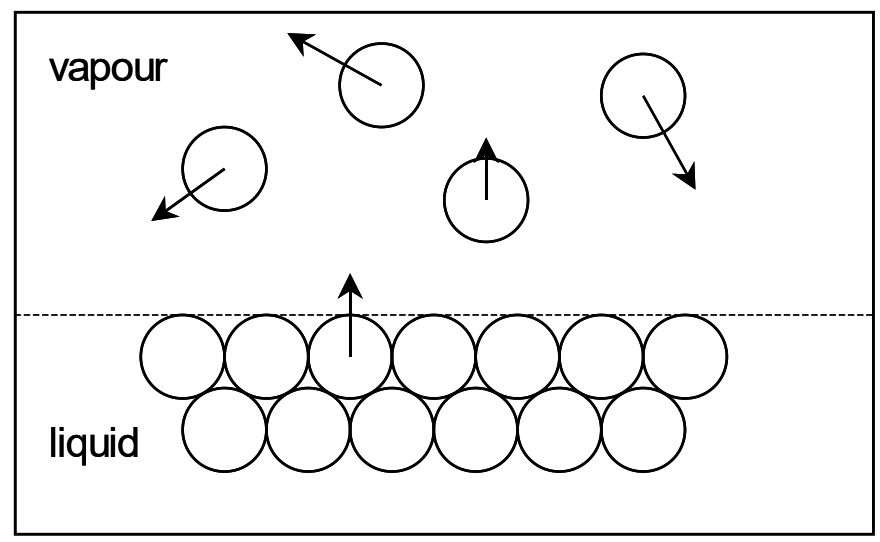

Figure A.1 Water molecules escaping from the liquid surface; some vapour molecules may return into the liquid.

Figuur A.1 Watermoleculen die ontsnappen aan het vloeistofoppervlak; een aantal dampmoleculen zou kunnen terugkeren in de vloeistof. 
at a higher saturated vapour pressure. It appears that saturated vapour pressure increases progressively with an increase in temperature. For instance, at $10^{\circ} \mathrm{C}$ saturated vapour pressure for water vapour is $1230 \mathrm{~Pa}$, while at $20^{\circ} \mathrm{C}$ it is almost doubled to $2340 \mathrm{~Pa}$ (see Appendix D).

Since evaporation (or condensation as the opposite process) is the net effect governed by the exchange of outgoing and incoming water molecules, the rate of evaporation can be estimated if the rates of molecular exchange at the liquid-air interface would be known. The rate of incoming (condensing) vapour molecules is related to the collision rate of vapour molecules with the liquid surface. In the next few paragraphs this rate is estimated using the ideal gas law.

Assuming the water vapour behaves almost like an ideal gas, the well-known law for an ideal gas describes the relation between pressure $p$, volume $V$ and absolute temperature $T$ :

$$
p V=n_{M} R T \quad[\mathrm{~N} \cdot \mathrm{m}]
$$

where $n_{M}$ is the number of moles of gas molecules in volume $V$, and $\mathrm{R}$ is the universal gas constant, $8.3144 \mathrm{~J} /($ mole $\cdot \mathrm{K})$. The number density of molecules in a given volume now follows from:

$$
n=\frac{n_{M} N_{A}}{V}=\frac{p}{k T} \quad\left[\mathrm{~m}^{-3}\right]
$$

where $N_{A}$ is Avogadro's number, $6.02 \times 10^{23}$ (i.e. the number of molecules in one mole), and $k=R / N_{A}$ is Boltzmann's constant, $1.38 \times 10^{-23} \mathrm{~J} / \mathrm{K}$. So if the vapour pressure and temperature are known, the number density of vapour molecules can be calculated easily.

The so-called 'kinetic gas theory' links molecular properties like number density and molecular velocity to macroscopic properties like gas pressure and temperature. From this theory, the number of collisions $q$ of gas molecules, per unit area of a wall and per unit of time, can be derived:

$$
q=\frac{1}{4} n v_{\text {avg }} \quad\left[\mathrm{m}^{-2} \mathrm{~s}^{-1}\right]
$$

where $v_{\text {avg }}$ is the average velocity of the vapour molecules. This velocity appears to be related to absolute temperature and molecular mass only:

$$
v_{\text {avg }}=\sqrt{\frac{8 k T}{\pi m}} \quad[\mathrm{~m} / \mathrm{s}]
$$

where $m$ is the mass of one water molecule, which relates to molecular weight $M$ (i.e. the mass of one mole of a substance) by $m=M / N_{A}$. Combining Eqs.(A.2), (A.3) and (A.4) 
gives the collision rate as a function of the macroscopic properties vapour pressure and absolute temperature:

$$
q=p \sqrt{\frac{1}{2 \pi m k T}} \quad\left[\mathrm{~m}^{-2} \mathrm{~s}^{-1}\right]
$$

Each incoming water molecule occupies a volume $V_{m l}=m / \rho_{W}$ in the liquid, which gives the condensation flux as the raise of liquid per unit time (if sufficient vapour would be present and the outgoing process would be neglected):

$$
Q_{\text {cond }}=q V_{m l c}=\frac{p}{\rho_{W}} \sqrt{\frac{M}{2 \pi R T}} \quad[\mathrm{~m} / \mathrm{s}]
$$

using $m=M / N_{A}$ and $N_{A} \cdot k=R$. For a saturated water vapour at $20^{\circ} \mathrm{C}$ (i.e. $T=293 \mathrm{~K}$ ) vapour pressure is $p_{\text {sat }}=2340 \mathrm{~Pa}$; further $M=0.018 \mathrm{~kg} / \mathrm{mole}$ and $\rho_{W}=998 \mathrm{~kg} / \mathrm{m}^{3}$ (see Appendix D). This gives a condensation flux of $Q_{\text {cond }}=0.0025 \mathrm{~m} / \mathrm{s}=2.5 \mathrm{~mm} / \mathrm{s}$ ! This huge flux seems unrealistic. Yet in practice the outgoing evaporation flux is of the same order of magnitude, approximately compensating the condensation flux. Besides, the transport of vapour molecules from the air towards the liquid surface is based on diffusion and is much too slow to keep up with the calculated condensation flux. If now evaporation flux would exist, the water surface would be covered almost immediately by a layer of dehydrated air.

Since at saturation both fluxes are equal, the evaporation flux in the example above also must be $2.5 \mathrm{~mm} / \mathrm{s}$. This flux of molecules leaving the liquid does not depend on vapour pressure above the liquid, and will be constant as long as water is present at the given temperature. If a cup of water would be exposed suddenly to dry air, evaporation starts at the given flux. Almost immediately the water surface would be covered by a layer of air saturated with water vapour, since again the diffusive transport of vapour molecules in air, this time away from the liquid surface, cannot keep up with the evaporation flux.

Though the above calculations seem rather strange and useless for practical purposes, they clearly show that evaporation and condensation are extremely fast processes. This means that wherever liquid water has an interface with air, the liquid surface is immediately covered by a layer of air saturated with water vapour. Consequently, the actual evaporation rate of such a surface will be determined by diffusion or convection (i.e. due to air flow across the liquid surface). 


\section{Appendix B. Evaporation as a process of diffusion}

The vertical transport of water vapour above an infinitely extended surface of water is described by the (1-dimensional) equation of diffusion. If $C(z, t)$ is the vapour concentration at height $z$ and at time $t$, the equation of diffusion is written as:

$$
\frac{\partial C}{\partial t}=D_{V} \frac{\partial^{2} C}{\partial z^{2}} \quad\left[\mathrm{~kg} \mathrm{~m}^{-3} \mathrm{~s}^{-1}\right]
$$

The factor $D_{V}$ is called the diffusion constant (the index $V$ indicates that the diffusing substance is the vapour) and has units $\mathrm{m}^{2} \mathrm{~s}^{-1}$. The above differential equation can be solved using a so-called Laplace transformation. For an imaginary liquid surface suddenly exposed to still air with constant vapour concentration $C_{0}$ (less than saturated vapour concentration), the concentration function turns out to be:

$$
\frac{C(₹, t)-C_{0}}{C_{S}-C_{0}}=1-\operatorname{erf}\left(\frac{z}{2 \sqrt{D_{V} t}}\right)
$$

where $C_{S}$ is the vapour concentration just above the liquid surface $(z=0)$; implicitly it is assumed that $C_{S}$ is a constant in time; erf 0 is the 'error function'. If the argument of the error function is larger than ca. 2 , the error function is approximately equal to 1 , and $C \approx C_{0}$ i.e. the local vapour concentration has not 'noticed' the presence of an evaporation surface yet. Thus, the thickness $\delta_{V}$ of the air layer with enhanced vapour concentration is given by:

$$
\frac{\delta_{V}}{2 \sqrt{D_{V} t}} \approx 2
$$

or:

$$
\delta_{V} \approx 4 \sqrt{D_{V} t} \quad[\mathrm{~m}]
$$

Apparently the thickness of the 'vapour layer' increases proportional to the square root of time. For water vapour at $20^{\circ} \mathrm{C}$ and $1 \mathrm{~atm}, D_{V} \approx 22 \cdot 10^{-6} \mathrm{~m}^{2} / \mathrm{s}\left(=22 \mathrm{~mm}^{2} / \mathrm{s}\right)$. Within about $0.003 \mathrm{~s}$ after exposing the liquid surface, the vapour layer has a thickness of $1 \mathrm{~mm}$; within $1 \mathrm{~s}$ the layer has grown to about $19 \mathrm{~mm}$ thickness (see Figure B.1).

The vapour flux at the water surface is given by:

$$
\Phi_{S}(t)=-\left.D_{V} \frac{\partial C}{\partial z}\right|_{z=0} \quad\left[\mathrm{~kg} \mathrm{~m}^{-2} \mathrm{~s}^{-1}\right]
$$




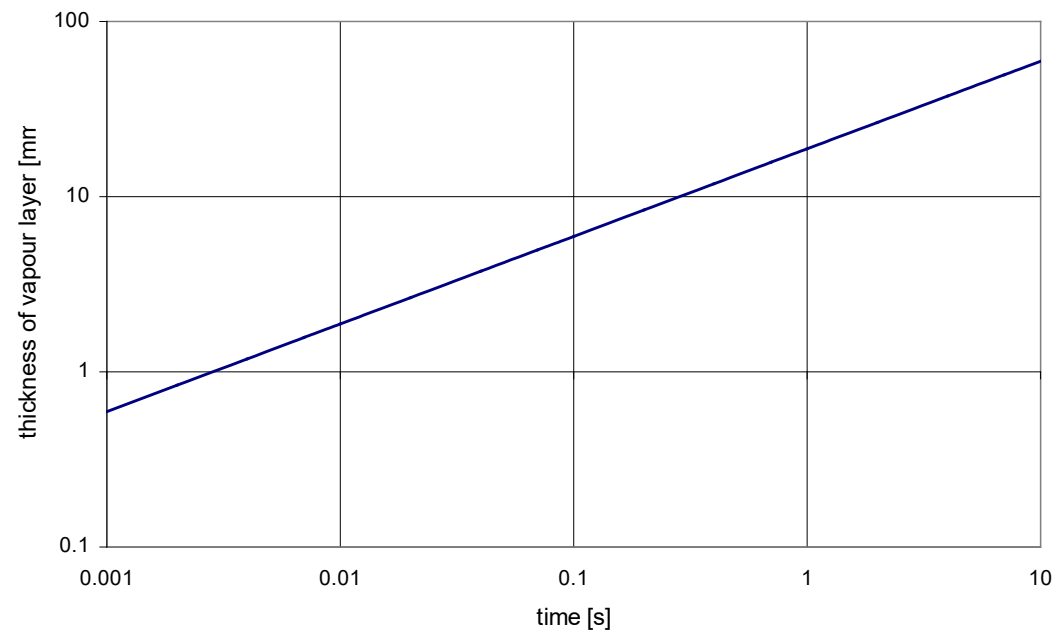

Figure B.1 Thickness of vapour layer above an infinitely extended water surface as a function of time, due to diffusive vapour transport in still air $\left(20^{\circ} \mathrm{C}\right)$.

Figuur B.1 Dikte van de damplaag boven een oneindig nitgestrekt wateroppervlak als functie van de tijd, bij damptransport alleen door diffusie; stilstaande lucht $\left(20^{\circ} \mathrm{C}\right)$.

where the gradient on the right hand side should be taken at the surface $(z=0)$. Since this gradient is negative, the minus sign on the right hand side returns a positive (upward) vapour flux. Using Eq.(B.2) the vapour flux leaving the surface equals:

$$
\Phi_{s}(t)=\left(C_{s}-C_{0}\right) \sqrt{\frac{D_{V}}{\pi t}} \quad\left[\mathrm{~kg} \mathrm{~m}^{-2} \mathrm{~s}^{-1}\right]
$$

At start $(t=0)$ the flux would be infinitely large; actually is it limited by the fast molecular exchange as discussed in Appendix A. The local vapour concentration is equal to $n \cdot m$, the product of (local) number density and mass of a single molecule. Using parts of the derivation in Appendix A, the vapour concentration is:

$$
C=\frac{p M}{R T} \quad\left[\mathrm{~kg} / \mathrm{m}^{3}\right]
$$

provided that the vapour can be considered to behave like an ideal gas. If at the liquid surface the vapour is saturated and at $20^{\circ} \mathrm{C}$ (i.e. $p_{\text {sat }}=2340 \mathrm{~Pa}$, see Appendix D), the vapour concentration at the liquid surface is computed from the equation above, giving $C_{S}=0.017 \mathrm{~kg} / \mathrm{m}^{3}$. In the most extreme case, i.e. $C_{0}=0$, the initial evaporation flux is largest, yet the net evaporation flux is rapidly decreasing with time. While the initial flux equals $2.5 \mathrm{~kg} / \mathrm{m}^{2} \mathrm{~s}$ according to Appendix A, only $0.01 \mathrm{~s}$ later the flux (Eq.(B.6)) has decreased to $0.00046 \mathrm{~kg} / \mathrm{m}^{2} \mathrm{~s}$, equivalent to a surface sinking rate of $0.46 \mu \mathrm{m} / \mathrm{s}$ (see Figure B.2). Obviously the diffusion process has an enormous effect on net evaporation flux and almost completely eliminates a rapid evaporation. 


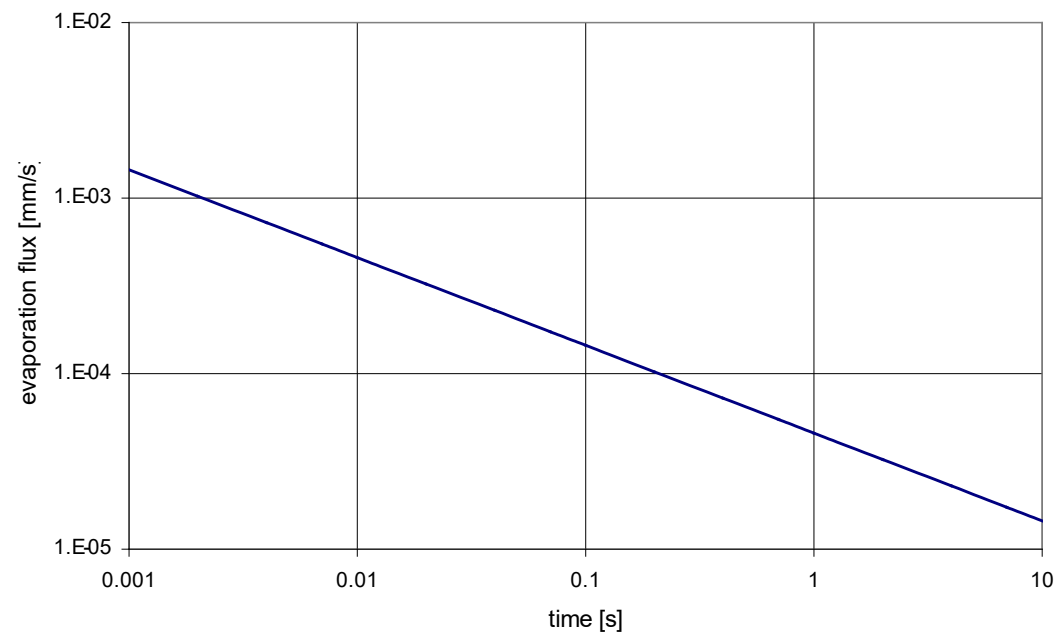

Figure B.2 Evaporation flux (expressed as surface sinking speed) as a function of time, due to diffusive transport in still air $\left(20^{\circ} \mathrm{C}\right)$; infinitely extended water surface assumed.

Figuur B.2 Verdampingsflux (uitgedrukt als daalsnelheid van het vloeistofoppervlak) als functie van de tijd, ten gevolge van transport door diffusie in stilstaande lucht $\left(20^{\circ} \mathrm{C}\right)$; een verondersteld is een oneindig uitgestrekt wateroppervlak.

In practice diffusion is not the only process of vapour transport. Often convective transport (i.e. air flow due to wind, or turbulence caused by vertical thermal gradients) is much more important than diffusion. 


\section{Appendix C. Vapour pressure and humidity}

Water vapour molecules in the atmosphere add to the atmospheric pressure. Their pressure contribution is called 'partial vapour pressure'. If the atmosphere is saturated with water vapour, the partial vapour pressure is called 'saturated vapour pressure'. Since molecular evaporation as well as velocity of vapour molecules are strongly dependent on temperature (see Appendix A), vapour pressure must be strongly dependent on temperature too.

Saturated vapour pressure for water can be well described by the following empirical equation:

$$
p_{\text {sat }}=610.7 \cdot 10^{7.5 T /(T+237.3)} \quad[\mathrm{Pa}]
$$

where $T$ is ambient temperature $\left[{ }^{\circ} \mathrm{C}\right]$. The first factor $(610.7 \mathrm{~Pa})$ is the saturated vapour pressure at $0^{\circ} \mathrm{C}$. Monteith and Unsworth (1990) refer to it as Teten's formula, but use slightly different constants. The above equation is valid for temperatures $0^{\circ} \mathrm{C}$ up to roughly $100^{\circ} \mathrm{C}$.

Clearly partial vapour pressure must have a value between 0 (i.e. completely dry air) and $p_{s a t}$. It may be convenient to express partial vapour pressure in terms of dry- and wet-bulb temperatures. Dry-bulb temperature merely is the normal ambient temperature. The following equation relates partial vapour pressure (at dry-bulb temperature) to these temperatures (List, 1958):

$$
p=p_{s a t, w}-\gamma\left(T_{d}-T_{w}\right) \quad[\mathrm{Pa}]
$$

where $p_{s a t, w}$ is the saturated vapour pressure $[\mathrm{Pa}]$ at wet-bulb temperature, $T_{d}$ and $T_{w}$ are dry- and wet-bulb temperature $\left[{ }^{\circ} \mathrm{C}\right]$, respectively, and $\gamma$ is a constant $\left(\approx 67 \mathrm{~Pa} / \mathrm{K}\right.$; at $15^{\circ} \mathrm{C}$ and $1 \mathrm{~atm})$. More accurately, $\gamma$ is a function of atmospheric pressure $B$ (in $[\mathrm{Pa}]$ ) and wetbulb temperature (in $\left[{ }^{\circ} \mathrm{C}\right]$ ) (List, 1958):

$$
\gamma=0.000660 B\left(1+0.00115 T_{w}\right) \quad[\mathrm{Pa} / \mathrm{K}]
$$

Relative humidity is defined as the ratio of partial vapour pressure and saturated vapour pressure (e.g. Monteith and Unsworth, 1990):

$$
R H=\frac{p}{p_{\text {sat }}} \quad[-]
$$

Sometimes one may need to know wet-bulb temperature, given ambient temperature and relative humidity. Though computing relative humidity from the bulb temperatures is straightforward, the other way round requires an iterative calculation process. Another useful approach for computational purposes is, firstly, to compute a table of $R H$ values for various values of $T$ and $T-T_{w}$. Secondly, from this table a polynomial fit can be obtained 
for $T-T_{w}$ as a function of $T$ and $R H$ by regression analysis. The initial table can be obtained using Eqs.(C.2), (C.3) and (C.4). If $T$ is limited to $10-20^{\circ} \mathrm{C}$, it turns out that at $R H=50 \% T-T_{w}$ is about $4-6^{\circ} \mathrm{C}$. With $B=101325 \mathrm{~Pa}(=1 \mathrm{~atm})$ and $T_{w} \approx T-5, \gamma$ can be approximated by

$$
\gamma \approx 66.87(1+0.00115 \cdot[T-5]) \quad[\mathrm{Pa} / \mathrm{K}]
$$

This estimation is independent of $T_{w}$ yet it ensures the errors made will be only small.

Regression analysis shows that $T_{w}$ can be well described by a relation linear in $T$ and quadratic in $R H$ (derived for $T=10-20^{\circ} \mathrm{C}$ and all $R H$ ):

$$
T_{w}=T-\left[\left(a_{0}+a_{1} T\right)+\left(b_{0}+b_{1} T\right) R H+\left(c_{0}+c_{1} T\right) R H^{2}\right] \quad\left[{ }^{\circ} \mathrm{C}\right]
$$

with constants:

$$
\begin{array}{ll}
a_{0}=5.1055 & a_{1}=0.4295 \\
b_{0}=-0.04703 & b_{1}=-0.005951 \\
c_{0}=-4.005 \cdot 10^{-5} \quad c_{1}=1.660 \cdot 10^{-5}
\end{array}
$$

if temperatures are given in $\left[{ }^{\circ} \mathrm{C}\right]$ and relative humidity in $[\%]$.

The error in estimated values of $T_{w}$ is relatively low, except for a relatively dry $(\mathrm{RH}<40 \%)$ and warm $\left(T>16^{\circ} \mathrm{C}\right)$ atmosphere. Error indications:

$<0.01^{\circ} \mathrm{C}$ for $\mathrm{RH}>40 \%$ and $T=10-20^{\circ} \mathrm{C}$;

$<0.1^{\circ} \mathrm{C}$ for all $\mathrm{RH}$ and $\mathrm{T}=10-16^{\circ} \mathrm{C}$;

largest error: $\sim 0.24^{\circ} \mathrm{C}$ for $\mathrm{RH}=0 \%$ and $\mathrm{T}=20^{\circ} \mathrm{C}$ 


\section{Appendix D. Various empirical equations}

This appendix contains empirical equations that can be used to accurately estimate various quantities, mainly as a function of ambient temperature. Most of these quantities vary only slightly in the range $0-20^{\circ} \mathrm{C}$. Therefore, for estimations that not require the highest degree of accuracy, values at for instance $15^{\circ} \mathrm{C}$ may be a good choice.

In general, temperatures $T$ are on an absolute scale (Kelvin scale). Sometimes, however, it is more convenient to use the Celcius scale; temperatures on the Celcius scale are denoted with index $C$ (i.e. $T_{C}$ ). Note that $T=T_{C}+273.15$.

\section{Density of humid air}

According to Weast (1986, page F-8), adapted for pressures in $[\mathrm{Pa}]$ rather than [mmHg]:

$$
\rho_{a}=1.2929 \cdot \frac{273.15}{T} \cdot \frac{B-0.3783 p_{V}}{1.01325 \cdot 10^{5}} \quad\left[\mathrm{~kg} / \mathrm{m}^{3}\right]
$$

where $B$ is the barometric pressure and $p_{V}$ (partial) vapour pressure (both [Pa]). Note that $1 \mathrm{~atm}$ is equivalent with $1.01325 \cdot 10^{5} \mathrm{~Pa}$. This clarifies the above equation: the first factor (1.2929) is the density of dry air at $0^{\circ} \mathrm{C}$ and $1 \mathrm{~atm}$, while the two following quotients can be interpreted as a correction for temperature and pressure, respectively.

At $15^{\circ} \mathrm{C}$ and $1 \mathrm{~atm}$, density varies from 1.218 (air saturated with water vapour; $p_{V}=1710 \mathrm{~Pa}$, see below) to $1.226 \mathrm{~kg} / \mathrm{m}^{3}$ (dry air; $\left.p_{V}=0 \mathrm{~Pa}\right)$.

\section{Density of water}

Weast (1986), page F-10, gives the following densities of pure water (free from air):

\begin{tabular}{cc}
\hline$T_{C}$ & $\begin{array}{c}\rho_{w} \\
{\left[\mathrm{~kg} / \mathrm{m}^{3}\right]}\end{array}$ \\
{$\left[{ }^{\circ} \mathrm{C}\right]$} & 999.87 \\
3.98 & 1000.00 \\
5 & 999.99 \\
10 & 999.73 \\
15 & 999.13 \\
20 & 998.23 \\
25 & 997.07 \\
30 & 995.67 \\
35 & 994.06 \\
40 & 992.24 \\
45 & 990.25 \\
50 & 988.07 \\
\hline
\end{tabular}


Fitting a parabola results in the following empirical equation:

$$
\rho_{w}=1000.0-0.00653\left(T_{C}-3.98\right)^{2} \quad\left[\mathrm{~kg} / \mathrm{m}^{3}\right]
$$

Error: $<0.1 \mathrm{~kg} / \mathrm{m}^{3}$. Valid temperature range: $0-30^{\circ} \mathrm{C}$.

Note that $3.98^{\circ} \mathrm{C}$ is the temperature where water has the highest density $\left(1000.0 \mathrm{~kg} / \mathrm{m}^{3}\right)$. On a wider temperature range $\left(0-50^{\circ} \mathrm{C}\right)$ the equation should be modified as follows, to keep the errors $<0.1 \mathrm{~kg} / \mathrm{m}^{3}$ :

$$
\rho_{w}=1000.0-0.0067\left(T_{C}-3.98\right)^{2}+5.2 \cdot 10^{-7}\left(T_{C}-3.98\right)^{4} \quad\left[\mathrm{~kg} / \mathrm{m}^{3}\right] \quad(\mathrm{D} .3)
$$

\section{Viscosity of air}

Weast (1986), page F-42, gives the following list of viscosities of air:

\begin{tabular}{cc}
\hline$T_{C}$ & $\eta_{\mathrm{a}}$ \\
{$\left[{ }^{\circ} \mathrm{C}\right]$} & {$\left[10^{-6} \mathrm{~Pa} \cdot \mathrm{s}\right]$} \\
\hline 0 & 17.08 \\
18 & 18.27 \\
40 & 19.04 \\
54 & 19.58 \\
\hline
\end{tabular}

From these values the following empirical equation was deduced:

$$
\eta_{a}=\left(17.1+0.067 T_{C}-0.0004 T_{C}^{2}\right) \cdot 10^{-6} \quad[\mathrm{~Pa} \cdot \mathrm{s}]
$$

Error: $<0.1 \cdot 10^{-6} \mathrm{~Pa} \cdot \mathrm{s}$. Valid temperature range: $0-54^{\circ} \mathrm{C}$.

At $15^{\circ} \mathrm{C}$ and $1 \mathrm{~atm}$, the equation above gives an air viscosity of $18.0 \cdot 10^{-6} \mathrm{~Pa} \cdot \mathrm{s}$.

\section{Diffusion coefficient of water vapour in air}

Gates (1980; his Appendix 3) gives the following list of diffusion coefficients:

\begin{tabular}{cc}
\hline$T_{C}$ & $\begin{array}{c}D_{V} \\
{\left[{ }^{\circ} \mathrm{C}\right]}\end{array}$ \\
\hline 0 & 21.2 \\
5 & 22.0 \\
10 & 22.7 \\
15 & 23.4 \\
20 & 24.2 \\
25 & 24.9 \\
30 & 25.7 \\
35 & 26.4 \\
40 & 27.2 \\
45 & 28.0 \\
\hline
\end{tabular}


A linear equation fits well $\left(\mathrm{R}^{2}=0.9997\right)$ :

$$
D_{V}=21.2 \cdot 10^{-6}\left(1+0.0071 \cdot T_{C}\right) \quad\left[\mathrm{m}^{2} / \mathrm{s}\right]
$$

This equation is very similar to the one proposed by Monteith and Unsworth (1990), who mention a gradient 0.007 rather than 0.0071 . However, Williamson and Threadgill (1974) use a power-law relation which turns out to give significantly lower values of the diffusion coefficient.

Error: $<0.1 \cdot 10^{-6} \mathrm{~m}^{2} / \mathrm{s}$. Validity range: $0-45^{\circ} \mathrm{C}$.

\section{List of precalculated values}

The above quantities, calculated from the given empirical relations, are listed below for a few common temperatures. For completeness saturated vapour pressure is added as well (see Appendix C).

\begin{tabular}{ccccccc}
\hline $\begin{array}{c}T_{C} \\
{\left[{ }^{\circ} \mathrm{C}\right]}\end{array}$ & $\begin{array}{c}\rho_{a, d y} \\
{\left[\mathrm{~kg} / \mathrm{m}^{3}\right]}\end{array}$ & $\begin{array}{c}\rho_{a, \text { wet }} \\
{\left[\mathrm{kg} / \mathrm{m}^{3}\right]}\end{array}$ & $\begin{array}{c}\rho_{w} \\
{\left[\mathrm{~kg} / \mathrm{m}^{3}\right]}\end{array}$ & $\begin{array}{c}\eta_{\mathrm{a}} \\
{\left[10^{-6} \mathrm{~Pa} \cdot \mathrm{s}\right]}\end{array}$ & $\begin{array}{c}D_{V} \\
{\left[10^{-6} \mathrm{~m}^{2} / \mathrm{s}\right]}\end{array}$ & $\begin{array}{c}p_{V, \text { sat }} \\
{[\mathrm{Pa}]}\end{array}$ \\
\hline 5 & 1.270 & 1.266 & 1000.0 & 17.4 & 22.0 & 870 \\
10 & 1.247 & 1.242 & 999.7 & 17.7 & 22.7 & 1230 \\
15 & 1.226 & 1.218 & 999.1 & 18.0 & 23.5 & 1710 \\
20 & 1.205 & 1.194 & 998.2 & 18.3 & 24.2 & 2340 \\
\hline
\end{tabular}

